Article

\title{
Pastures and Cash Crops: Biomass Flows in the Socio-Metabolic Transition of Twentieth-Century Colombian Agriculture
}

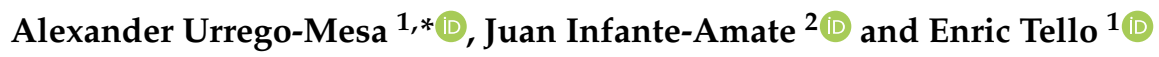 \\ 1 Department of Economic History, Institutions, Policy and World Economy, University of Barcelona, \\ 08034Barcelona, Spain; tello@ub.edu \\ 2 Agro-ecosystems History Laboratory, Pablo de Olavide University, 41013Sevilla, Spain; jinfama@upo.es \\ * Correspondence: alex.urrego.mesa@ub.edu; Tel.: +34-934021931
}

Received: 13 November 2018; Accepted: 20 December 2018; Published: 26 December 2018

\begin{abstract}
This article aims to situate a national case study of the global periphery at the core of the debate on the socio-ecological transition by drawing on new data of biomass flows in twentieth-century Colombia. We draw up a century-long annual series converting a wide set of indicators from Net Primary Production (NPP) into the final socioeconomic uses of biomass, distinguishing around 200 different categories of crops, forests, and pastures. Our calculations draw on FAOSTAT and several corpuses of national statistics. The results show a fall of $10 \%$ in total NPP related to land-use changes involving forest conversion. Throughout the twentieth century, pasture was the most relevant among domestic extraction. Allocations of cash crops to industrial processing rose while the figure for staple crops for primary food consumption stagnated. The critical role of cattle throughout all periods and the higher yields of the industrial cash crops are behind this profile. This might also mean the start of a new trend of using pasture land for more profitable export crops, which establishes a new inner frontier of land-use intensification. Lastly, the article points out the phases of the socio-metabolic transition of biomass, explores the changes in biomass flows by looking at the history of the main drivers, and identifies the socio-ecological impacts of deforestation and industrial agribusiness.
\end{abstract}

Keywords: social metabolism; material flow accounting; biomass flows; net primary production; land cover and land-use change; deforestation; land-grabbing; inequality; Colombian agrarian system

\section{Introduction}

Over the twentieth century, economic and population growth led to unprecedented levels in the appropriation and use of energy and materials worldwide [1]. Although resources such as fossil fuels and other minerals dominated this increase, the appropriation of biomass has continued to grow. This is driven by increases in population along with incomes and dietary changes [2,3]. This process has shaped the profile of fossil fuel-based agroecosystems [4-6] increasing the environmental pressures on nature. The amount of nitrogenous fertilizers used in agriculture around the world has moved from 11 million to 109 million in the last half-century, which is a ten-fold increase [7]. Global biomass extraction increased by $60 \%$ between 1980 and 2013 [8], while the proportion of the world's area being harvested increased by $40 \%$ from 1990 to 2014 [7].

Pollution, soil erosion, the decline in biodiversity, and damage to human health and deforestation, especially of tropical rainforests $[9,10]$, are among the main consequences and challenges of industrial agriculture [11]. However, despite the trilemma of challenges posed by the energy, environment, and food [12], it is still possible to confront the environmental impacts of farming and the projected 
rise in the demand for food, feed, biofuel, and other biomass-based resources by increasing the efficiency of nutrients and water use, reducing waste, and changing diets, policies, and agricultural practices [3,13-15]. Biomass is essential to the economy [16], but it is also crucial to ecosystems and the functioning of the landscape. The cycling of biomass flows within agroecosystems plays a valuable role in promoting crop productivity, maintaining farm-associated biodiversity, and preserving underground life forms by restoring eroded soils and improving their organic matter content, fertility, and structure. Biomass is also a critical element in nutrient and carbon cycles $[13,17,18]$. Therefore, the careful management of biomass flows is a key element along the path towards more sustainable forms of agriculture. To that end, a better understanding of the historical roots of the changes in biomass production, appropriation, and uses are essential to new agro-ecological forms of the management of biomass chains.

The most used approach when it comes to analyzing biomass flows at national scales is human appropriation of net primary production (HANPP) [19-21], defined "as the aggregate human-based effect of land-use induced changes in productivity and biomass harvest on the energy availability in ecosystems" [22] (p. 48). Although HANPP provides an assessment of human intervention in the biosphere, even in the long run [23], it does not provide a detailed picture of Net Primary Production (NPP) chain flows, and the works focus mostly on Europe [24]. In another way, material flow accounting (MFA) has become a standardized methodology for the study of the extraction and use of material flows, including biomass [25-27]. Although MFA does not always account for biomass production in detail, ignores the belowground flows of biomass, and the biomass in circulation (see Section 2.1 for details), it is a useful tool for the studies at the national scale. MFA has been directly or indirectly used in several case studies such as in Spain [28], Finland [29,30], Czechoslovakia [31,32], and even on a global scale [33,34]. All these cases have relied on the MFA approach, but they all also provide additional indicators on production, use, or input consumption. However, none of these papers focus on developing economies, and just three of them provide a historical perspective.

In this paper, we present, for the first time, a long-term estimation of the biomass flows in a developing, tropical, American economy. There is new data on NPP, extraction and use of biomass from crops, pastures, and forest between 1915 and 2015 in Colombia. Our main goal is to provide a biophysical reading of agrarian change as well as to identify the timing and features of the (un)sustainability of farming carried out in Colombia during the period. Using new, detailed information, it analyzes changes in land use and biomass extraction to identify the critical points at which the agricultural sector may have constituted a burden to the ecosystems, which places the global periphery at the core of the debate over the agrarian socio-metabolic transition.

Colombia represents a fascinating case study within Latin America for the socio-metabolic study of biomass flows for several reasons. The country is representative of a medium-sized economy in the region. GDP (at current US\$) in the country in 2016 was around 282 billion, which is very close to Chile (247) and twice bigger than the GDP of Ecuador, Paraguay, Bolivia, and Uruguay, and half of the GDP of Argentina. Concerning the population, after Mexico, the country is the second largest with 48 million inhabitants. It is comparable to Argentina (43), Peru, and Venezuela (31) [35]. Lastly, and more importantly, the country is the second largest biodiversity reservoir around the globe. Following the data from Biodiversity Information System in Colombia (SiB) [36], the country occupies the first place in birds and orchids, the second in plants, amphibians, butterflies, the third in reptiles and palms, and the fourth in mammals. Biological variety is the result of the differences among its ecosystems, including tropical forest in the Amazon and Chocó, mountain ecosystems in the Andes, or grasslands and meadows in the East of the country [36], which is why biodiversity loss in Colombia is a global issue. The study of the biomass flows during the twentieth century in Colombia places the socio-metabolic transition of an exporter country and a developing economy from Latin America into the framework of changes in western agriculture. The ecosystem variety and the differences between the tropical and Andean agriculture inside the country could be a benchmark for future research in the 
region. In addition, this kind of approach can contribute to a better understanding of the long-lasting violent political conflict in Colombia.

The remainder of the article is structured as follows. The second section explains the methodological approach, sources, and treatment of data. In the third section, we present the main series on land uses, NPP by types of land cover, the extraction and the uses of biomass, livestock figures, and crop yields. We attach the series of the NPP, extraction, and uses in the supplementary document. Lastly, we discuss the results in light of the main phases of the socio-metabolic transition and offer an initial exploration of the main drivers and the socio-ecological impacts of the changes in the composition of biomass flows.

\section{Materials and Methods}

\subsection{Methodological Approach}

MFA provides a broad set of indicators, including domestic extraction (DE), the physical trade balance (PTB), and domestic material consumption (DMC), by identifying four major material categories: biomass, construction minerals, fossil energy carriers, and ores. MFA is considered a good proxy for environmental impacts [37-39], as it helps us understand the material basis of economic development and has proven useful in the study of socio-ecologically unequal exchange [40-43]. The long-term analyses made so far cover the crucial change from solar-based to fossil-based systems throughout the twentieth century in the United Kingdom [44], Austria [45], Japan, the United States of America, Czechoslovakia [31], and Spain [46]. The "medium-term" approach is the most common in the analysis of less developed countries (LDCs). Since 1960-1970, socio-metabolic studies have been conducted for India [47], the Lao People's Democratic Republic [48], Chile, Ecuador, Mexico, Peru [49], Brazil, Venezuela, Bolivia [50], and Colombia [51,52].

These works offer a comparative view of the pressures associated with material extraction in the world regions examined. They stress the role of LDCs as exporters of materials and energy carriers from the 1970s onwards [53], income growth as the main driver of the per capita increase in global material use, and the large gap in material living standards that exists between developed countries and the rest of the world [54-56]. However, in the MFA framework, biomass is only an item in the aggregated flows of national extraction from natural systems. Aggregated MFA indicators may be dominated by just one material category like copper in Chile [57] or fossil fuels in Saudi Arabia [54]. In these cases, the analysis fails to shed light on the role of other groups of materials or economic sectors and their environmental impacts.

In consequence, the estimation of biomass flows within MFA approaches tend to be very narrow and simplified. Therefore, it does not capture the complexity of production, the extraction, and the final use of biomass flows. We identify four items in which MFA accounting fails to provide a detailed picture of the biomass flows in a given economy where the changes in production and use of biomass may entail an environmental burden.

- The MFA approach focuses on extraction, not in production, so it is no possible to assess the actual impact of extraction.

- MFA only considers aboveground flows and not the belowground ones despite its ecosystem functions $[1,58]$.

- MFA does not provide a homogenized system to measure the biomass flows. Only in the case of pastures, the methodology suggests quantifying the flows in dry matter while the rest of biomass flows are accounted in fresh matter [59].

- Lastly, the MFA approach does not consider the biomass flows that recirculate nor the final uses of all the extracted biomass.

For the reasons above, we account for a set of biomass flows by drawing on recent methodological proposals for the study of energy and material flows in both present-day and historical 
agro-ecosystems [58,60-62]. First, we estimate actual net primary production (NPPact), understood as "the sum of harvested NPP, as reported in statistics, and other fractions not recorded in agricultural statistics" [19] (p. 12946). The NPP of agro-ecosystems takes into account the share of NPP used for humans (food, feed, fibers, and fuel), and the fraction of NPP remaining and used in the reproduction of other species living in the agro-ecosystems [58]. NPP accounting is the addition of the main plant product $(\mathrm{P})$, usually labeled "gross agrarian production", the associated by-products or residues from crops (CR), i.e., the rest of the aboveground production of the plant, the NPP of weeds (W), the belowground NPP or roots (R), and, lastly, the accumulated biomass in aerial trunks and branches (A). It can be written as follows.

$$
N P P_{t j}=P_{t j}+C R_{t j}+R_{t j}+W_{t j}+A_{t j}
$$

In Equation (1), $t$ refers to the specific year adopted as the time frame and $j$ to the land use, namely crops $(\mathrm{C})$, pasture $(\mathrm{P})$, and forest $(\mathrm{F})$. The addition of the NPP of theses uses also corresponds to the total NPP accounted here and can be written as follows.

$$
N P P_{t}=C_{t i}+P_{t i}+F_{t i}
$$

The $i$ in Equation (2) is the cover type of each land use e.g., maize, oil palm, or other crops, in the case of crops, pasture and shrub land for pasture, and the types of forest detailed below.

\subsection{Sources}

The data were gathered from official and secondary sources for the first half of the century and FAOSTAT for 1961 to 2015. The main categories covered were farming active population, total population, crop production, livestock numbers, and land use. From the population data, we used the decennial census and FAOSTAT [7] to arrive at the shares of agricultural and urban population. However, for the total population, we used the corrections made by Flórez et al. [63]. Cropland, crop production, and livestock data were gathered from 1915, 1933, 1934, and 1937 Statistical Yearbooks [64-67], supplemented by reports to the US government that provide data for 1925-1928 [68] and 1948-1967 [69]. For 1925, there is information on production from Sánchez [70], Diot [71], the Revista Nacional de Agricultura [72], and Bejarano [73]. Between 1934 and 1946, the primary source is Varela [74]. The production series for twelve crops (1915-1950) and cattle (1915-1997) offered by Kalmanovitz et al. [75] were also used with the latter being supplemented after 1997 by figures from FAOSTAT [7].

Data on the land-cover forest were derived from Etter et al. [76] figures on deforestation and land-cover figures regarding the forest in 1990, 2000, 2005, and 2010-2015 [77], the tropical dry forest in 2010 [78], the Andean forest and the rainforest in 1996, and another forest cover. In 1996, the latter included the fragmented basal forest, the riparian forest, the planted forest, mangroves, and other minor covers [79] (p. 284). We gathered pastureland figures for 1915, 1950, 1960, and 1970 in the Statistical Yearbook [64], Varela [74] and the agrarian census [80,81]. As of 1992 we used the addition of grassland and shrub-covered categories from the annual land cover maps (1992-2015) produced by the Université Catholique de Louvain (UCL)-Geomatics for the Climate Change Initiative (CCI) [7], since the values for 2013 are very close to those for land covers obtained from the agrarian census for 2014. Series for the forest wood production are available in FAOSTAT "Forestry" from 1961 to 2017 [7], and firewood series in the Unidad de Planeación Minero Energética of the Colombian Ministerio de Minas y Energía from 1975 to 2016 [82]. For the period before 1961, we relied on data on wood exports collected for 1916, 1922, 1923, 1938, 1945, and 1955 from the Statistical Trade Yearbooks [83-87].

\subsection{Data Processing}

Between 1915 and 1960, the series covers 30 crops and one aggregate category for fruits other than bananas and plantains. The entirety of production in our assessment for 1960 reaches $87 \%$ of 
the production of the FAOSTAT database for 1961. It is from 6.1 Mt dm in 1960 to $7.1 \mathrm{Mt} \mathrm{dm}$ in 1961. After 1961, we rely on FAOSTAT "Crops Production" database [7]. Annual area and coproduction missing values between 1915 and 1955 were obtained using linear interpolation, per-capita variables or adjusts in the original data (see Supplementary Materials Table S1). The results were checked with the available yields obtained from sources for the years either side of the one being considered and with the yields of other Latin American countries during this period such as Argentina (1909, 1925-1926) [88,89], Costa Rica $(1925,1927)$ [90], Cuba (1945) [91], Ecuador (1938-1942) [92], Bolivia, Brazil, Chile, Peru, and Venezuela (1949) [93] (see Supplementary Materials Section 2). Cropland is the sum of the area being harvested and the land lying fallow.

Using the scientific literature, we calculated the by-products or residues and the biomass roots of each crop, differentiating between traditional and conventional varieties when such information was available. We also differentiated between the biomass of weeds associated with crops depending on the type of farming management that prevailed throughout the century (traditional, low-input and conventional). Lastly, all flows were reduced to dry matter content and expressed in tons. The information on conversion factors was compiled from Guzmán et al. [58] and Montero [94], which is being expanded to achieve the aims of the study by going into depth in the literature review (see Supplementary Materials Table S2). Lastly, to match the two series (pre-FAOSTAT and FAOSTAT) and, in order to simplify our analysis, the crops were aggregated into 27 categories and then re-aggregated into 10 final categories: cereals, pulses, root \& tubers, vegetables, fruits, oil crops, fiber crops, stimulants, sugar and sweeteners, and other plant products (see Supplementary Materials Table S3).

In the case of forest land, we break down the aggregation of "forest" data into the rainforest, the tropical dry forest, the Andean forest, and another forest cover. The latter was calculated by subtracting specific covers from the general forest. Given the lack of available data before 1961, forest cover was estimated by using the rates of change in the historical series of forest clearing in Colombia calculated by Etter et al. [76] (see Supplementary Materials Table S4). This back projection uses, as its starting point, the series of forest covers made available from the 1990s onwards thanks to satellite images. The NPP of each type of forest was calculated by applying productivity factors taken from Scurlock and Olson [95] to the area by the type of forest. Domestic extraction figures are the result of matching the series for wood production (removals) and firewood [7,82]. For the period before 1961, we used the series resulting from the Statistical Trade Yearbooks of Colombia [83-87], which have been matched with FAOSTAT. We have also adjusted this series for the period before 1975 with the available data for per-capita firewood consumption in rural areas for that year, which was adjusted by comparing the proportion of the rural population with the figure for the total population between 1915 and 1975.

In the pastureland, we identify two main categories: pasture, understood as the amount of land allocated for grassing, and shrubland \& others, which is known as a mixture of land for grassing and secondary vegetation resulting from the changes in the forest use. For the first category, we figured the cattle density for the years with available data from 1950, 1960, 1970, and 1992-2015 (see Supplementary Materials Table S5). We got the missing years using the steady ratios by periods including 1915-1950, 1951-1960, 1961-1970, and 1971-1992. When figures for the areas of crops, fallow, forests, pastures, infrastructures, other lands, and land area were available, the residue was labeling "shrubland \& others." We positively validated our estimations by reviewing other available sources: "permanent meadows and pastures" from FAOSTAT for 1961-2015, the values of the land-cover map for 2010-2012 [96], and the agrarian census for 2014 [97] (see Supplementary Materials Section 4.2).

We obtained NPP for tropical and seeded (or improved) grasses using the NPP productivity factors in the literature [95,98-102]. The extraction of grassland is equal to the total animal feed requirements minus animal feed from crops, imported feeding, and a fixed percentage of crop residues taken from literature [33]. To calculate animal feed intake, we employ nutritional requirements for cattle, pigs, sheep, goats, horses, mules, and donkeys in respect of their weights [98,103-106]. Where 
possible, we adjusted these weights historically [68,83-87,107-110] (see Supplementary Materials Tables S6 and S7). We test the results by performing a sensitive analysis of our series (see Supplementary Materials Section 5.3). Seed, feed, and imported feeding were retrieved from FAOSTAT "commodity balances" as of 1961. Since we do not have data on seeds and animal feeding before 1961, we assume the same percentage as the one retrieved from FAOSTAT from 1961 to 1963.

Regarding the final uses, we distinguish five categories, namely: animal feeding, wood and fuelwood, recycled biomass, cash, and staple crops. Animal feeding is the addition of residues use as feed, the feed from crops, and the extraction from pasture. Wood and fuelwood include the removal of wood, firewood, and charcoal. Recycled biomass is composed by the piece of crops allocated to seeds and the crop residues not included in the animal feeding. Crop production is split in cash and staple crops. The former includes fibers, oil crops, the piece of sugar cane allocated to the industry to be processed, and the production of the stimulants category. The latter is the addition of cereals, pulses, tubers, vegetables, fruits, and the piece of sugar cane used directly as food.

\section{Results}

\subsection{Land Use Changes}

Colombia's land area is 110 Mha, the main cover being forests, with an average proportion of $54 \%$ between 2005 and 2015 (60.1 Mha average). However, at the beginning of the twentieth century, this figure was 68\% (76.2 Mha), and it was consistently higher than 65\% (72 Mha) until 1964 (see Figure 1). The area under the forest fell from 76 to 59 Mha during the twentieth century. This average loss of $22 \%$ was more profound in the case of the Andean forest than in any other forest cover, especially since the 1970s, due to the historically higher population densities in this region $[76,111]$. The share of the Andean forest over the total land area fell more than half, from $19 \%$ to $8 \%$, during that period. The tropical dry forest has represented a tiny part of the whole forest area and, although its deforestation has slowed since the 1970s [76], it is at risk of disappearing entirely [78]. The rest of forest covers have stayed almost constant at around 12 Mha.

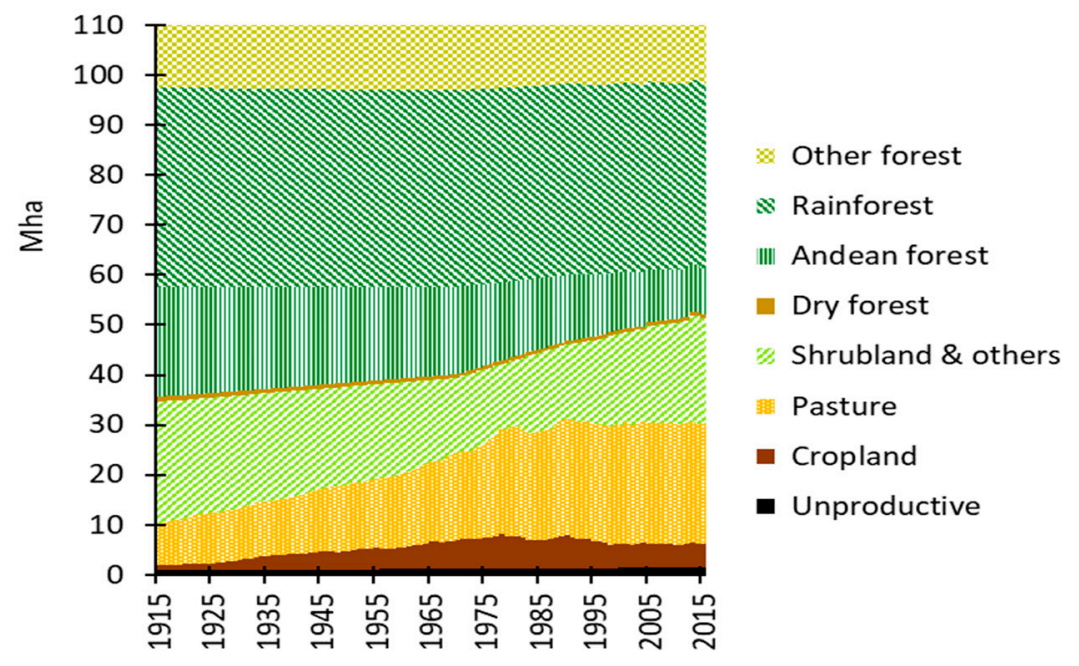

Figure 1. Land uses by groups in millions of hectares from 1915 to 2015. Source: own calculations from the sources given in the text.

The categories of pasture and shrub land \& others combined represent the second largest type of cover, which accounts, on average, for a third of the land area during the 1915 to 1984 period, but, by the mid-1970s, this figure rose and presently represents more than $40 \%$ of the total land area. Pasture and shrubland increased the area from 32.6 Mha in 1970 to 45 Mhas in 2015, but it is worth remembering that, in our series, the shrubland \& others land use is a residual category whose fluctuations reflect the dynamics of the other types of land cover. However, it has some interesting features. Between 1915 and 
1980, it fell from $21 \%$ (24.5 Mha) to $12 \%$ (13.2 Mha) due to the expansion of cropland and pastureland. After the 1980s, shrubland and others recovered and reached 19\% (21 Mha) in 2014 while cropland stagnated and the growth in grass pasture slowed. At the beginning of the period, the pastureland represented only $8 \%$ (17.3 Mha) of total land area. It doubled during the 1970 s and since the early 1990s covers more than $20 \%$ (24 Mha in 2015) of the total land area.

Lastly, although the area under cropping is only a small part of the total land area, its change is even more significant than that of pasture. The cropland experienced a four-fold increase between 1915 and 2015, which moved up from 0.9 Mha (1\% of land area) to 5 Mha (4\%) and reached its highest point in 1978, 6.9 Mha (6\%). The process of cropland expansion was more intense during the first half of the century (1915-1964), with an annual rate of growth of $3.6 \%$ than during the second half (1965-2015), when the growth stagnated. The intensification of agrarian production under industrial management and increases in imports of staple food items are the main factors behind the stagnation of the agricultural frontier, which we will discuss below.

Regarding the area harvested by crops (Figure 2), we can divide the frontier expansion into three sub-periods. In the first two periods, intensive ploughing is observed. From 1915 to 1944, the cropland annual growth was $4.5 \%$ and, from 1945 to 1974 , it was 1.5\%. However, after 1975, the agricultural frontier stagnated, with an average annual rate of growth of only $0.3 \%$ (Figure 2a).

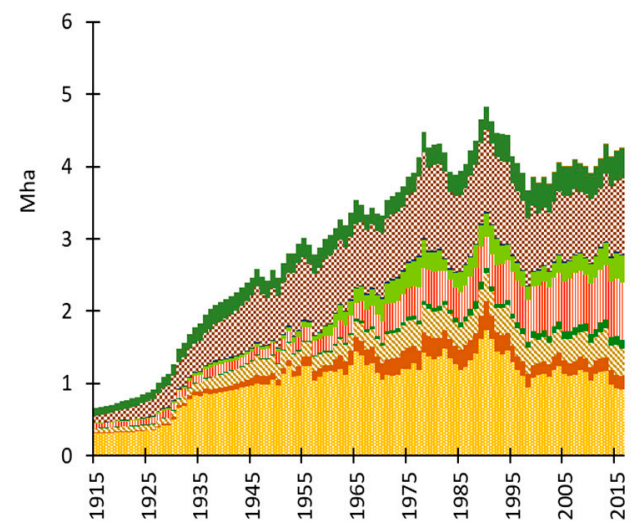

(a)

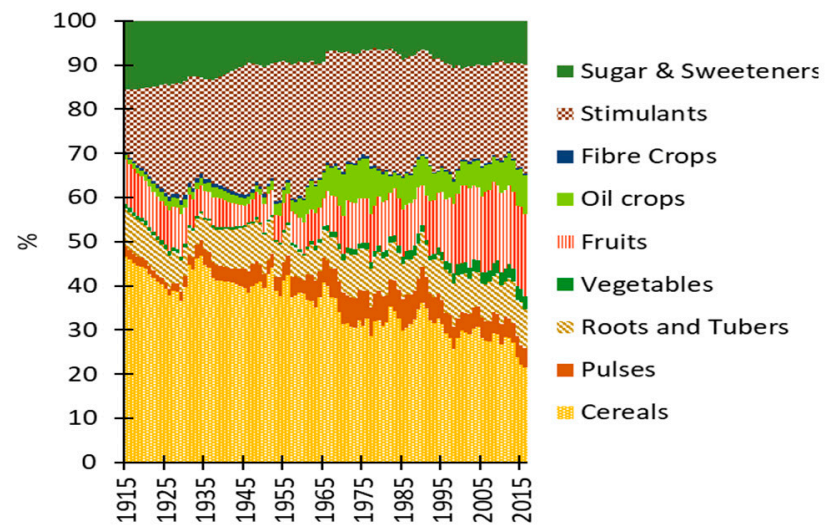

(b)

Figure 2. (a) Area harvested by groups of crops in millions of hectares and (b) as a percentage between 1915 and 2015. Source: own calculations from the sources given in the text.

By looking at crop compositions, we observe that staples have traditionally been the largest crop group. Their percentage over total cropland area has barely changed during the analyzed period, which moved from $55 \%$ to $43 \%$. However, if we focus on cereals, we observe a sharper drop (Figure $2 b$ ). Between 1915 and 1954, cereal crops occupied more than 40\% of the area harvested. Afterwards, their share lost importance by up to $27 \%$. From 1915 to 1960, the reduction in the proportion of arable land devoted to cereals was offset by the increase in the production of stimulants, especially coffee, which moved from $11 \%$ to $29 \%$. However, the share of land under coffee plantations fell after that date and reached $20 \%$ of the cropland area in 2015. Fruit crops (both traditional and new ones) and oilseed crops have filled the gap left by the contraction in the cropland areas of coffee and cereals (see Figure 2b). Among oilseeds, the oil-palm fruit stands out and has expanded since the late 1980s with a share of $8 \%$ of the total area harvested at present.

\subsection{The Long-Term Trend in NPP}

During the analyzed period, the NPP experienced a 10\% reduction from $2 \mathrm{Gt}$ in 1915 to $1.8 \mathrm{Gt}$ in 2015 (Figure 3). Between 1915 and 1994, the annual rate of change was, on average, $-0.13 \%$. However, after that year, it fell to $-0.04 \%$. In other words, although we observe a long-term pattern of decline in NPP, as of the 1990s it stagnated. Nevertheless, the volatility of the short-term variation of the NPP 
increased during the second half of the century. The standard deviation of the annual rates from 1915 to 1964 was $0.07 \%$, but it more than doubled from 1965 to 2015 (Figure 3b).

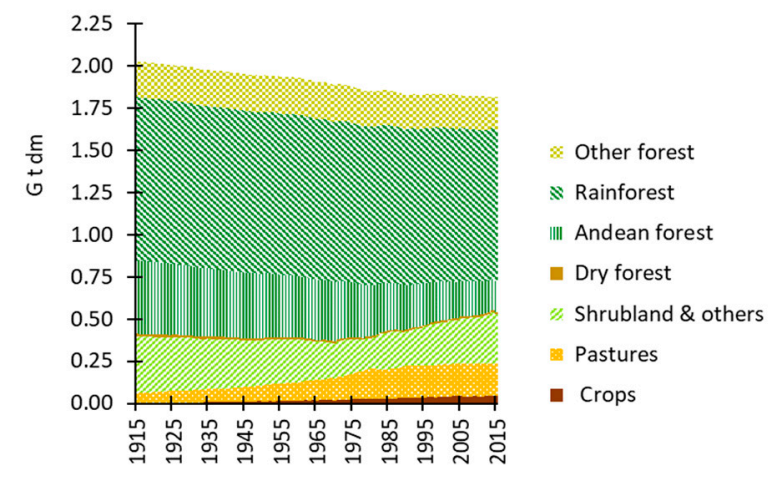

(a)

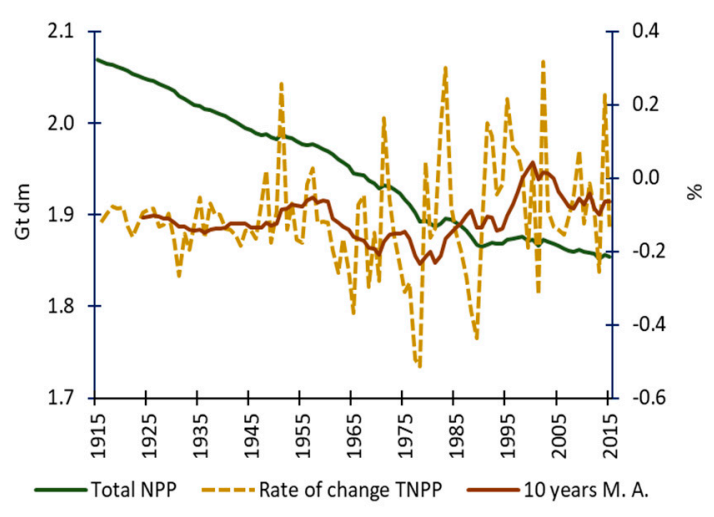

(b)

Figure 3. (a) NPP by groups in giga-tons of dry matter, 1915-2015. (b) Total NPP in giga-tons of dry matter, rates of change, and 10-year moving average in percentage (right axis), 1915-2015. Source: own calculations from the sources given in the text.

The weight of the NPP in forest lands dominates the composition of the NPP. It comprised $80 \%$ of the whole NPP until 1974, but from 1975 to 2015, its share fell from $78 \%$ to $71 \%$. However, there have been sharp disparities in the trend and composition of the different types of forest. The main component of the whole NPP in forest lands is rainforest, which is the most productive and the primary land cover in most of the country (see Figure 1). Although its area has been reduced, its NPP contribution to the total has stayed almost constant at near 50\% of total NPP. Conversely, the Andean forest reduced its NPP share by half, from $21 \%$ to $11 \%$, which fell in absolute numbers from 434 to 184 Mt throughout the period.

The NPP of pastureland and shrub land, where there is also secondary vegetation, fell from $19 \%$ to $18 \%$ between 1915 and 1974 . This slight reduction corresponds to the shrub land NPP falling from $22 \%$ to $13 \%$, or from 487 to $298 \mathrm{Mt}$ in absolute figures, and a rise in the pasture NPP from $3 \%$ to $7 \%$. After 1975, the NPP figures for pastures and shrub land recovered somewhat, increasing from $11 \%$ to $15 \%$ of the total share. This increasing trend was opposite that for the forest, especially the $10 \%$ reduction in the Andean forest NPP. The pasture and shrub land NPPs rose by $0.75 \%$ during this period of growth. However, the major gains were achieved for shrub land. The increase in the pasture NPP mainly took place during the first period at an average annual rate of $1.6 \%$ between 1915 and 1974, when the shrub land NPP was falling, and did not occur during the second period.

Similar to pastures, but to a lesser extent, the share of the NPP in cropland rose from $0.2 \%$ in 1915 to $2 \%$ in 2015 . Despite it having only a tiny share of total NPP, the increases in the NPP for crops were the most dynamic, even more than those for pasture, which means a nearly fifteen-fold increase from 3 to $44 \mathrm{Mt}$ throughout the century. The average annual rate of growth in cropland NPP was $3 \%$ for the whole period. By grouping this increase in 10-year periods, the annual growth rates fell from $3 \%$ to $0.1 \%$, and there are three different sub-periods. The 1915-1944 period saw the most exceptional period of growth at $4.5 \%$. From 1945 to 1974, the growth rate experienced a slight reduction down to $3 \%$, but then recovered from 1955 to 1964 by $4 \%$. Lastly, there was a period of lower growth of around $2 \%$ between 1975 and 2015, which is followed by an apparent fall in the growth rate at the beginning of the 21st century (Figure 4a). 


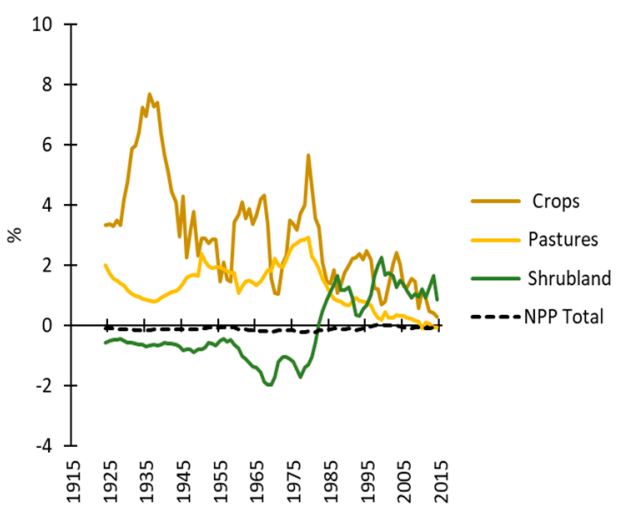

(a)

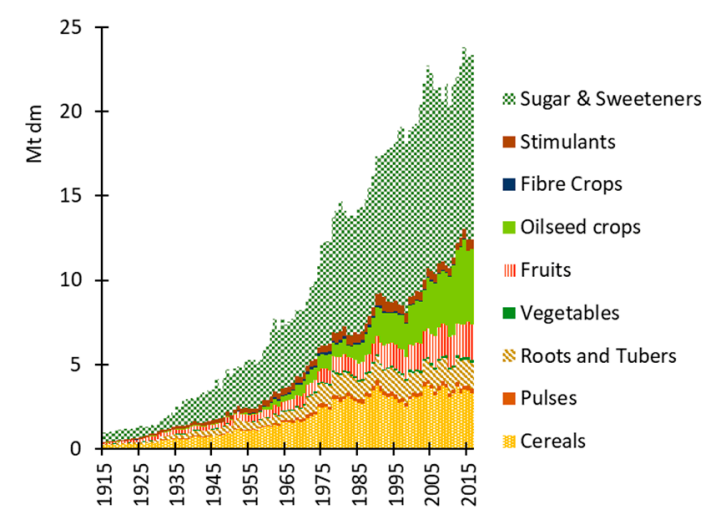

(b)

Figure 4. (a) Rates of change in NPP for cropland, pastureland, shrub land, and total NPP. Mobile 10-year average. (b) Crop production by groups in millions of tons of dry matter, 1915-2015. Source: own calculations from the sources given in the text.

By groups of crops, the most basic division into arable and permanent crop production initially seems favorable to the second one. Staple food crops such as cereals, pulses, tubers, and vegetables shared on average $30 \%$ of NPP production in cropland during the whole century while cash crops like fruits, oilseed crops, fibers, stimulants, and sugar or sweeteners produced the other 70\% (sd. 4.5). The first feature that stands out is the importance of sugar and sweeteners, with an average share of $50 \%$. Although there are some variations during the period, the standard deviation is low (sd. 5). The most significant change is observed in the decreasing trend in the share of basic grains of $22 \%$ between 1915 and 1924, falling by up to 16\% from 2005 to 2015, and a total drop during the analyzed period of $7 \%$. The stimulants group, headed by coffee, also reduced its share from $8 \%$ to $2 \%$ between 1925 and 1934. Conversely, oilseed crops, mainly palm oil, increased their share from mid-century onwards and represent 7\% from 1965 to 1974 and 17\% from 2005 to 2015.

\subsection{Final Uses of NPP Extraction}

Domestic extraction (DE) of biomass increased nearly three-fold during the period. Meanwhile, total NPP fell by $10 \%$. Consequently, the DE share of total produced phytomass increased from $1 \%$ to $6 \%$. Of this total, the grassland experienced the most significant degree of extraction with a share of $70 \%$ on average throughout the whole 1915-2015 period. However, the share of grassland fell from $80-70 \%$ before the 1960 s to $60 \%$ in the 2010s (Figure 5a and Figure 7). The second largest extraction was of crops, which is a third of total DE in the last several years. In the long run, the categories in the second position of DE components experienced a switch. From 1915 to 1960, this position was occupied by forest extraction, but from 1970 onwards, the increasing trend in crop extraction surpassed the share of forestry. After this tipping point, forest extraction fell from $17 \%$ to $7 \%$ in 2015 . This process was driven by the reduction in fuelwood consumption due to the energy transition to "modern" energy carriers, which are mainly fossil fuels [52].

The uses of biomass extracted from Colombian agriculture also reveal the importance of the biomass devoted to animal feed (Figures $5 b$ and $6 a$ ), especially that from pastureland grazed by cattle. Although the composition of the livestock intake included significant amounts of crop production, residues, and even imports as contributions to the supply of animal feed, pasture dominated the nutrition of herds by far, particularly cattle, the central element in livestock composition (see Section 3.4). The pasture was nearly the only source of feed until 1970. After this date, its share fell from $99 \%$ to $88 \%$ in 2015 , since the increase in crop yields raised the space for feeding livestock. Feed imported from abroad started to rise from the beginning of the 21 st century, but it only represents $5 \%$ of the animal feed extracted from domestic agro-ecosystems. 


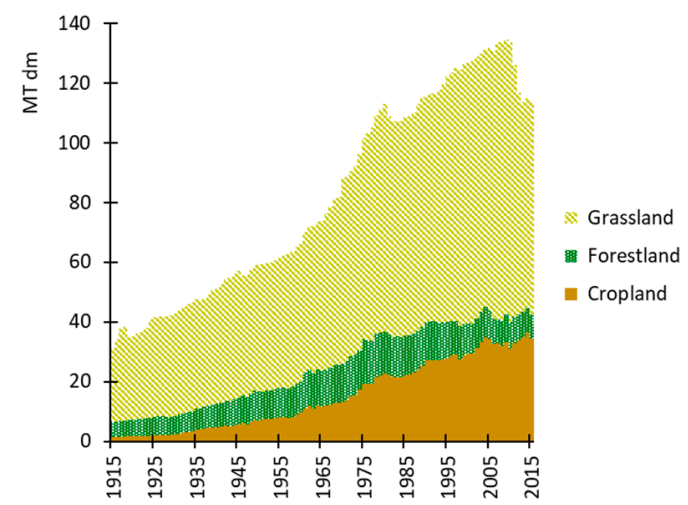

(a)

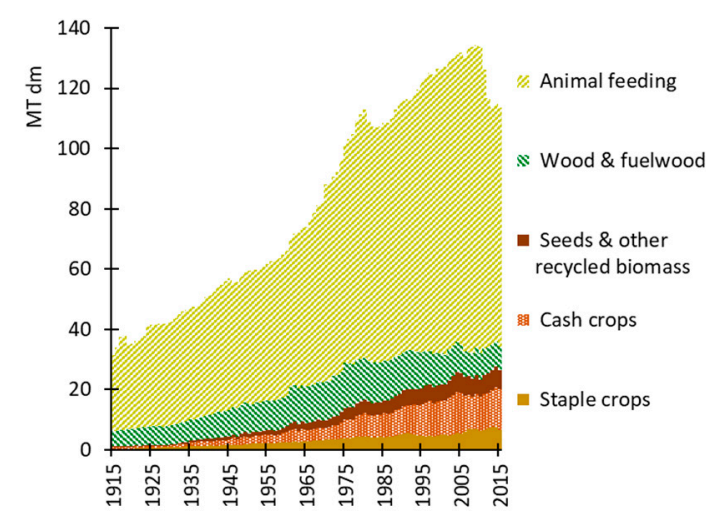

(b)

Figure 5. (a) Domestic extraction and (b) final uses of biomass in millions of tons of dry matter, 1915-2015. Source: own calculations from the sources given in the text.

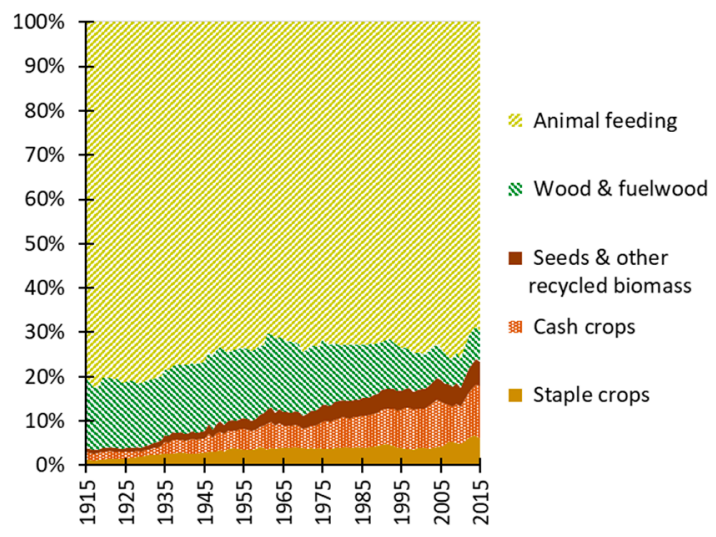

(a)

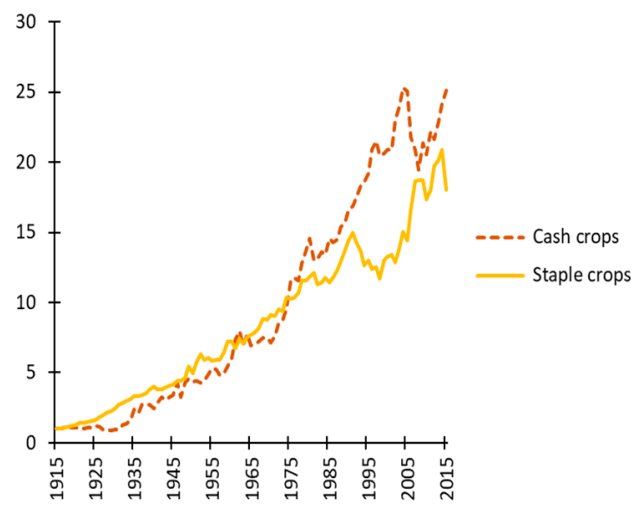

(b)

Figure 6. (a) Final uses of biomass extraction in percentage from 1915 to 2015. (b) Index figures of the biomass devoted to primary food and processing industries and others from 1915 to 2015. 1915=1. Source: own calculations from the sources given in the text.

If we go more deeply into the uses of cropland extraction, the most relevant feature is that primary foodstuffs like cereals, pulses, tubers, or vegetables represent a smaller component than the biomass flows from the cash crops such as fibers, sugar cane, or oil-palm fruit (Figures 6a and 7). Only after the food crisis at the end of the 1920s did the amount of primary food for human consumption exceed the amounts of biomass produced in cash crops. At that time, biomass flows of both primary foodstuffs and for market purposes were 3\% to $4 \%$ of the whole DE. In 2015, the biomass flows extracted from cash crops shared $13 \%$ of the total $\mathrm{DE}$, while primary food remained at around $6 \%$.

The primary staple food rose in absolute terms from 0.3 to $2.3 \mathrm{Mt}$ until 1950-1960, when it achieved a share of $4 \%$ of DE. Subsequently, this share remained almost flat, at $4-5 \%$ up to 2010 , when it experienced a slight increase. The biomass devoted to the processing industries through the markets ran almost parallel to that used for primary food until 1970. Yet, with a slightly lower index, until 2015, its share rose from $5 \%$ to $13 \%$ at a higher rate than staple food (Figure $6 \mathrm{~b}$ ). 

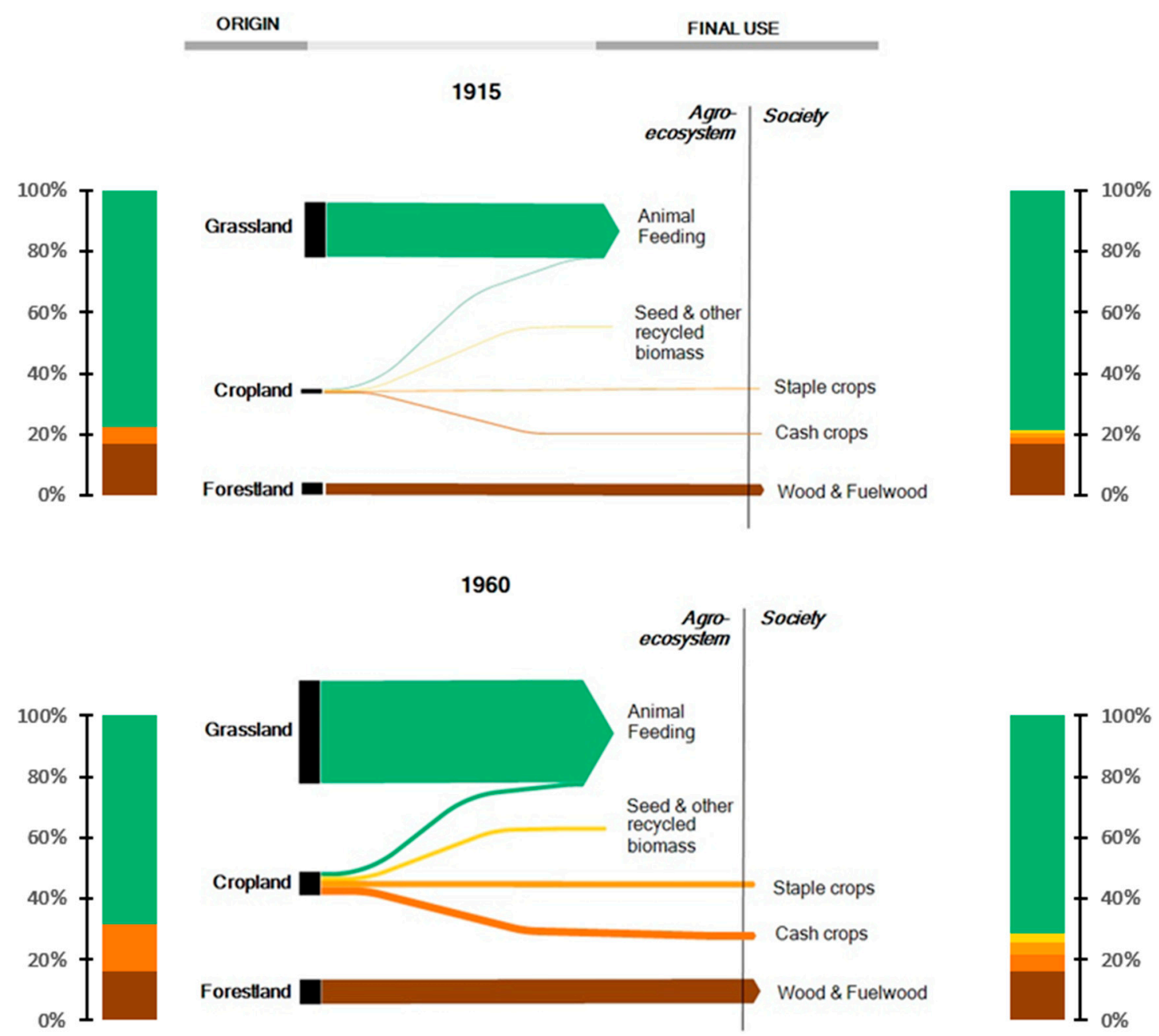

2015

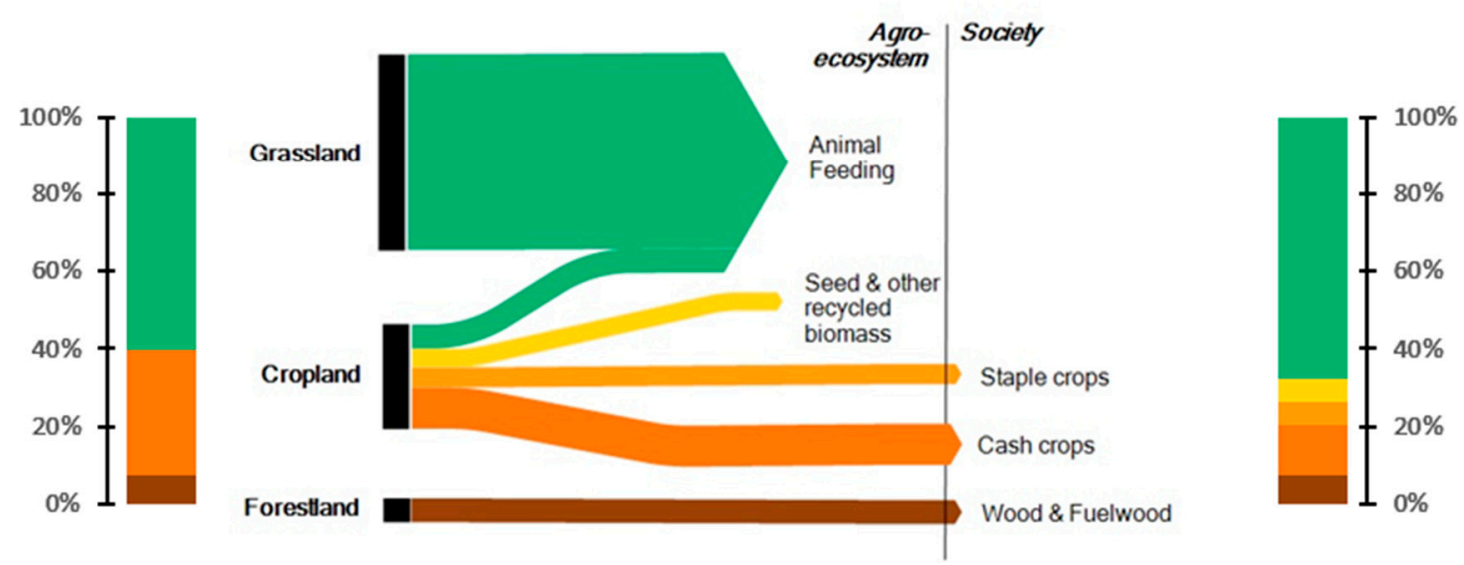

Figure 7. Biomass flows from domestic extraction to final uses. Millions of tons of dry matter, and its share for 1915, 1960, and 2015. Source: own calculations from the sources given in the text.

\subsection{Livestock and Cropland Intensification}

The two main long-term features in the fund-flow metabolic pattern of Colombian agriculture have been the dominance of animal feeding extracted from grassland, especially for cattle, and the dynamism of the cash crops through the industrial intensification of farming. Measured in live units 
(LU) of $500 \mathrm{~kg}$, the national livestock herd rose two and a half times from 5 to 17.5 LU500 between 1915-2015 (Figure 8). This increase is due practically entirely to the growth in cattle numbers, which accounted for more than $80 \%$ of total livestock fresh weight throughout the period. This increase from 4 to 14 LU500 shaped the general trend, except during the first decade of the 21st century, when it experienced a slight reduction. The reasons for this reduction in the national herd are related to the increasing prices of meat since 1991 that led to a fast de-accumulation of cattle stock to get fresh money, in accordance with the speculative management of the livestock [7] as well as the increase of violence that rose from the kidnapping of breeders and from cattle thefts [112]. The number of kidnappings in Colombia increased from 442 to 3456 from 1995 to 2000 and remained at 1356 kidnappings a year on average from 2004-2010 [113]. Lastly, the main long-term changes in livestock composition have occurred with the fall in the number of mules and donkeys and the increase in pigs and poultry in both absolute and relative terms.

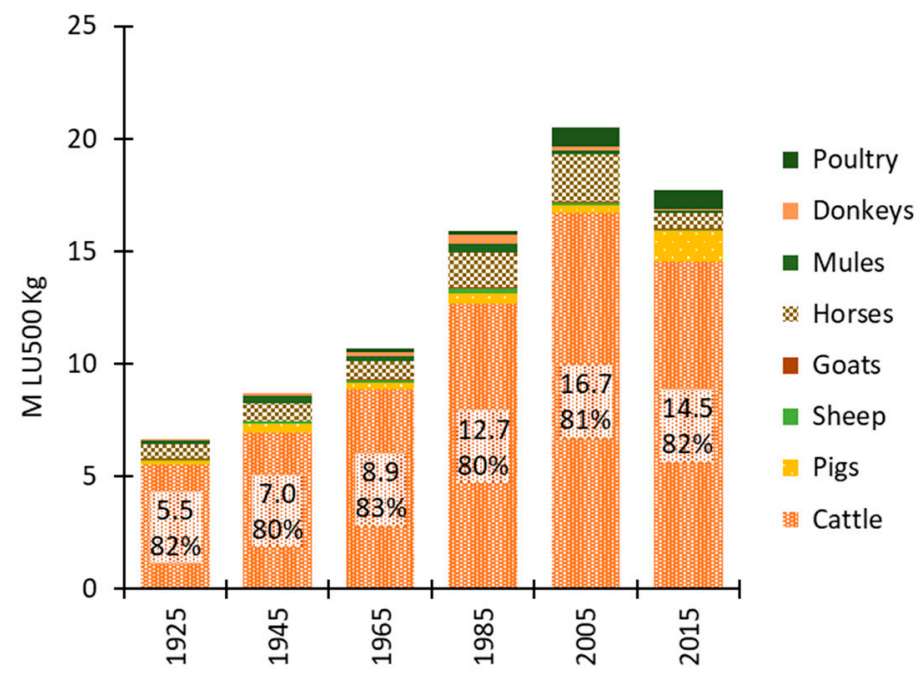

Figure 8. Livestock in millions of LU 500kg for 1925, 1945, 1965, 1985, 2005, and 2015. Source: own calculations from the sources given in the text.

Regarding crop intensification, the indices of domestic crop extraction and area harvested show a close relationship from 1915 to 1945/55 (Figure 9a), which means that land productivity remained relatively stable. During this period, the increase in production was very land (and labor) dependent. However, after 1955, and especially from 1970 onwards, production growth decoupled from the land. Since then, increases in yield have driven the DE trend for crops since the 1990s when the area harvested fell (Figure 9a). The average yield of the total biomass extracted per unit of cropland more than doubled between 1915 and 2015 and rose from 1.4 to 5.5 tons of dry matter per hectare. Although there had been some increases in these average yields during the 1930s, the actual change in the trend in yields took place from about 1950 onwards and accelerated until 2000, after which the average yield stagnated (Figure 9b).

Yield trends differed between staple crops and cash crops. The yields of cereals not only remained under average, but they also grew less than cash crops such as sugar and sweeteners and oilseeds. Yields of sugar crops have risen since the 1930s, moving from 3 to 26 tons of dry matter per hectare between 1930 and 2015. The oilseed yield increased after 1950, moving from 0.6 to 11.6 tons of dry matter per hectare between 1950 and 2015. However, the increase in cereal yields was suddenly interrupted between 1975 ( 2 tons of dry matter per hectare) and 1995 (2.2) and again from 2003 to 2013 (2.8). Sugarcane became by far the most intensive crop. Nevertheless, this yield had already been attained in 1979 and has remained at that ceiling ever since. 


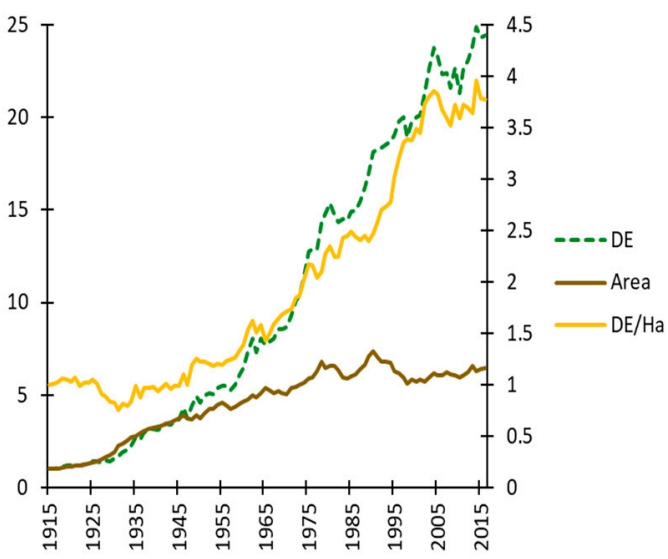

(a)

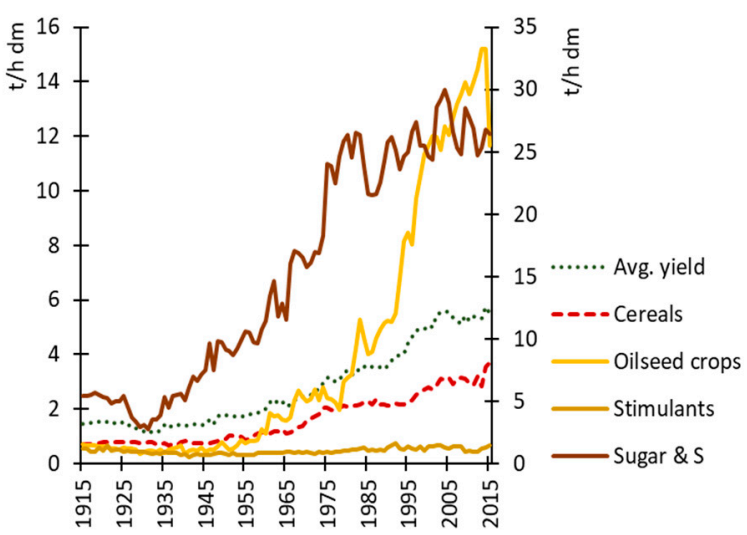

(b)

Figure 9. (a) The index of biomass extracted from crops and area harvested. DE: domestic extraction from crops and area (left axis) 1915=1. Yields of DE (DE/Ha) (right axis). (b) Average yields of the biomass extracted from crops and yields by groups of crops. Sugar and sweeteners at the right axis. Tons per hectare in dry matter. Source: own calculations from the sources given in the text.

\section{Discussion}

\subsection{Phases of the Socio-Metabolic Transition of Biomass}

Socio-ecological transitions are historical changes in the appropriation and use of natural resources by societies including one that took place two hundred years ago and involved the massive use of fossil fuels $[114,115]$ However, there are differences in these transitions at the regional [116] and sectoral levels [117]. In the case of the appropriation and use of biomass flows, we identified three main phases during the industrial socio-ecologic transition.

Until about 1950, the profile of the production and appropriation of biomass is one of the pre-industrial organic economies. The main characteristic of these economies is that production was mainly dependent on land [114,116]. Most consumption goods came from biomass flows like fuelwood for houses and industries, animal feed to provide power for transport and traction, and food for humans. The severe energy restrictions on long terrestrial transport distances reinforced the need for close spatial relationships between land use, livestock feeding, and human consumption. Production and consumption were tightly linked geographically $[118,119]$.

In Colombia, before about 1950, grains and roots dominated the production and appropriation of biomass from crops. The area under these crops amounted to 1.2 Mha, which is more than half the harvested area. During the first half of the twentieth century, there was a strong correlation between the area harvested and agricultural production. While there was some room to improve yields, the possibilities were scarce in the pre-industrial era. During that first phase, the constraints in agriculture entailed a trade-off between staple crops and cash crops, especially coffee and cereals, which caused a severe food crisis at the end of the 1920s and required the state to intervene actively in agriculture in the 1930s. The basic grains and other staple crops continued to be an essential agricultural element in both production and area. Cash crops like sugarcane and bananas had already increased their yields due to earlier intensification, but the increases in production during this phase were mainly achieved by taking more land into cultivation. This enlargement of the agricultural frontier deeply affected the Andean forest [76,120], while cattle-ranching gained ground at lower altitudes in order to supply the increasing demand from the cities [121].

During the second phase, from about 1950 to 1990, the expansion of the area under staple crops, especially cereals, stagnated, while the area under cash crops continued to expand. From 1965 onwards, increases in yield became widespread among other cash crops, like coffee and oilseeds. The biomass extracted for industrial processing predominated over primary foodstuffs. Cereals achieved major 
increases in yield of all staple crops, as intended by the Rockefeller Foundation through the Green Revolution [112]. There are no aggregated data on fertilizer consumption, but the spending of the Instituto Colombiano Agropecuario (ICA) on agrarian research and to implement the Green Revolution increased from $0.1 \%$ to $0.7 \%$ of agricultural GDP between 1965 and 1990 [112]. The result was the decoupling of DE from the area harvested as well as the gains in yields that drove the increasing production of biomass for the cash crops, which is clearly shown in our series. The pastureland continued to expand, whereas shrub land and other secondary vegetation following deforestation started to increase in some areas. This did not mean that the expansion of the agricultural frontier came to an end since more land was devoted to export-led crops like sugarcane, oil palm, and tropical fruits. Meanwhile, deforestation had already taken half of the NPP from the Andean forests and was beginning to expand over the lowland rainforests.

A halt in advancing the colonization frontier characterized the last phase (1990-2015). When seen at the aggregated national level, an overall reduction in cropland took place for the first time over the century being analyzed. The area harvested was reduced from 4.8 to $4.2 \mathrm{Mha}$. Within them, significant areas of land under basic grains have been abandoned even though the area under old and new cash crops like coffee, bananas, other tropical fruits, flowers, and oil palm has been stabilized. Per capita grain production rose from 0.04 to 0.11 tons of dry matter between the $1920 \mathrm{~s}$ and the end of the 1970s. From that moment, per capita grain production fell up to 0.07 tons in 2015.

This indicates the emergence of a new process of externalizing the supply of primary food in Colombia. These trends suggest that the socio-metabolic patterns of production and use of biomass are increasingly being affected by international trade, with profound relevance for food sovereignty and security. This is a topic that needs to be addressed in future studies. From a preliminary appraisal of biomass trade flows and apparent consumption, we calculate that, from 1990 to the present, the contribution of net biomass imports has risen from $10 \%$ to $38 \%$ of Colombian consumption [7].

Many pieces of research indicate that gains in yields, and even some recent energy efficiency improvements in the production and use of industrial inputs for farming [122], are leading to a new trend in land use involving forest transition [123]. However, the Colombian case looks more complex. There was a slight reduction in average yields during this phase, while the new cash crops like oil palm and other tropical fruits continued to expand the cropland area-to which the illegal cultivation of coca must be added. At the same time, other crops like sweeteners (mainly sugarcane) or stimulants (mainly coffee) reached a ceiling in intensification and a reduction in the area harvested during this phase. Together with the simultaneous reduction in the pressure of cattle requirements on grasslands, this presented an opportunity to decrease or even halt deforestation rates from 2010 to 2015 [77]. These are only the main national trends, and they differ strongly when the actual regional and local trajectories are examined. Despite apparently being opposed, they all represent processes of specialization that are closely linked to the same international trade relationships, which are being driven by an agro-food system that is increasingly global.

\subsection{Socioeconomic and Political Drivers of the Changing Metabolic Profile of Colombian Agriculture}

Land availability, productivity, livestock, trade, population density and increases in incomes are among the main drivers of the changing patterns of biomass use [33] and HANPP [23] that have been identified both globally and nationally. Studies of land use and cover change (LUCC) carried out both nationally and regionally in Colombia have identified similar socio-economic variables that explain the expansion of the agricultural frontier and its impacts on deforestation. In older settlement areas, these main drivers are related to high population densities and intensive forms of agriculture that have transformed Andean ecosystems. Meanwhile, the growing occupation of large areas of pasture for use by cattle-grazing appear to be associated with other extensive forms of land use, low population densities, and impacts on tropical lowland forest, especially after the 1970s [111]. After clearing, the introduction of pasture is the most common type of cover replacement in the lowlands [111,124], and, in the long run, cattle has been responsible for the major transformations in land use country-wide. 
However, population growth, industrialization, and the illegal drugs economy are also included in the LUCC analysis [76].

We describe the evolution of trade and agrarian policies, the role of cattle in land-grabbing, the industrialization of agriculture, and other factors like economic growth, increases in living standards, and changes in diet. We look at these subjects in history as a first scan of the main factors behind changes in production, extraction, and uses of the biomass flows. These flows have been dominated by the dynamism and prominence of producing cash crops for the processing industries and the extension of pasture to satisfy livestock requirements.

\subsubsection{Trade and Agrarian Policies}

The origins of Colombia's modern economic development are rooted in the establishment of the coffee economy $[73,125,126]$. After years of civil war, the country embraced the last opportunity offered by international trade. Export promotion and protection policies were introduced by the government of Rafael Reyes (1904-1909). The collapse of the traditional large plantations in the east of the country due to the Thousand Days' War, the fall in global prices, and the emergence of agrarian conflicts [125] left some room for small and medium-sized farms to develop in new areas of colonization in the west-center of the country [127], where the area under coffee was expanded.

Agro-exports were the main stimulus increasing the agricultural production [128]. However, the capacity to produce primary food, especially cereals, was not as successful as for cash crops. At the end of the 1920s, the state had to deal with a significant food crisis $[73,112]$ and increasing pressure from coffee growers by reducing tariffs in 1927 and tackling the effects of the world economic crisis during the 1930s. It did this by increasing public spending and giving the public policy a more active role in the economy [129].

The main tools of economic policy were tariffs, currency devaluations, and trade controls on imports of agricultural products, together with support for imports of farming inputs up until the 1950s [112,129]. State intervention evolved from merely expanding the transport infrastructure before 1930 and tackling the effects of the 1930s crisis to redirecting financial credit to strategic sectors, intervening in coffee production and markets through quotas, and increasing social spending and infrastructure investment. Public spending as a share of GDP grew from $9.7 \%$ to $17.6 \%$ from 1950 to 1970 [130]. New institutional support was implemented by founding sectoral banks, public agricultural research, and experimental stations as well as promoting tobacco, cotton, barley, and cattle as alternative agricultural products and backing private federations of farmers and cattle-ranchers [130].

From the mid-century onwards, these efforts were mainly focused on modernization and productivity gains rather than achieving more equitable forms of land tenure and rural incomes, diversifying the agro-export model, and opening up trade after the 1990s. During the 1960s, the model based on coffee exports began to be amended in which the main aim was then to industrialize Colombian agriculture using technical support and credit. This policy encouraged the growth of the agri-business class and commercial agriculture but neglected smaller farmers. After the 1970s, credit was increasingly extended to cattle-ranchers [112]. The end of the "golden age" of economic growth (1967-1974) opened the door to export led-growth, which is a change from the years of state-led growth [130,131]. New crops, which are different from coffee, such as flowers, sugar, or tropical fruits, increased their share of exports, while the growing imports of cereals helped reduce the price of food. However, the dimension of international trade seems to have accelerated un-precedently as of the 1990s. This last period represents a turning point towards re-emphasizing primary production in the insertion of the national economy in the global markets in a way that entails a loss of food sovereignty [52].

\subsubsection{Cattle Ranching as a Tool of Land Dispossession}

Although the policies that were implemented to transfer public land were intended to promote the expansion of the agricultural frontier, which offered an opportunity to increase small farmers' 
access to the land. In the long run, they mainly favored the concentration of landed property. During the 1930s, large amounts of public land were allocated in the west-center, where coffee had taken off. Subsequently, the average size of the public land delivered was reduced in this zone, but the number of allocations was the highest until 1960 [132]. After a wave of peasant conflicts in the 1930s the colons received some support in securing their property rights $[125,133]$. Law 200/1936 was mainly aimed at increasing agricultural production, but it also placed limits on the under-utilization of land and initially made some feeble attempts at land reform. However, between 1944 and 1959, this policy of redistribution was reversed. The land policy clearly aimed at guaranteeing the rights of the larger property-owners [132-135]. Although some attempts were again made to redistribute land after the period of the Violence (1948-1958) under the political umbrella of President Kennedy's Alliance for Progress (1966-1970), this was opposed by the associations of large landowners and cattle ranchers through the so-called Chicoral Pact agreed by the Colombian elites in 1972, which was promulgated in Law 4a/1973 [136]. The smallholders' protests and land invasions increased during the 1970s [137], but new laws were approved such as Law 30/1988, which prohibited the legalization of any occupied land.

A new opportunity for peasants escaping from violence in the Andean region came in the form of the colonization of some marginal regions in the lowlands like Caquetá and Putumayo. In the first case, the colonization, which was led by the state, did not provide enough support for the peasants to keep the land under the plough, and, ultimately, it was larger properties and pastures that took over the cleared forest [138]. In the second case, colonization by the small farmers was only maintained because of the expansion of the illegal coca economy [139]. In any case, deforestation of the rainforest was a common result.

An important outcome of these public policies, which fostered increasingly unequal land distribution, has been the huge share of fertile land taken over for the pasture compared to that devoted to crops, and the extraordinarily high proportion of the total biomass extracted represented by cattle-ranching (Figures 5b, 6a and 7). This important feature is closely linked to a long-used mechanism whereby Colombian elites have taken control of the territory. After an initial phase extending the agricultural frontier through slash-and-burn carried out by peasant colonizers under precarious forms of land entitlement, the big landowners kick these tenants out and seize the cleared lands by putting their cattle out to graze on them $[76,120,140]$.

The institutional arrangements developed throughout the twentieth century to avoid any attempt to increase small farmers' access to land ownership has given Colombian elites an easy way to grab a large share of land from the advancement of the colonizing frontier, which mainly ends up in the hands of the larger cattle-ranchers [141]. In 1960, 58\% of all Colombian pasturelands were in the hands of $16 \%$ of cattle-ranchers [142] (p. 84). The Gini index of land distribution in 1970 was $74 \%$ [143] (p. 5), which was already very high. However, it rose to 84\% in 1984 and 88\% in 1996 [144] (p. 11). From 1984 to 2003, the share of the total agricultural area in the hands of landholdings of less than 20 ha, which represented $85 \%-86 \%$ of all properties, decreased from $14.6 \%$ to $8.8 \%$. Conversely, the share of large estates of more than 500 ha. increased from $32.7 \%$ to $62.6 \%$ [145].

From 1980 to the present, four million peasants have suffered land-grab-induced displacements violently perpetrated by paramilitaries with the consent and help of many Colombian politicians and public institutions $[141,146]$. A strong correlation has been found between municipalities with higher Gini index of land concentration and those that have witnessed an increase in the forced displacement of dispossessed peasant communities. Far from emerging from a stateless situation, in Colombia, land-grabbing has been carried out using military violence to uproot peasant families from the land in order to force them to emigrate. As throughout the world, land-grabbing processes depend on the active role of the state $[147,148]$.

Besides creating a cheap workforce from a poor rural population that has been deprived of access to the expanding colonization frontier [140,142], this long-term process of land-grabbing has turned the land-livestock nexus into a financial asset largely benefiting from tax exemptions and public subsidies 
from the Colombian state $[137,149]$. The socio-economic and political rationale behind this land-cattle nexus has gone far beyond the simple business of ranching [141]. All sectors of the Colombian elite, as well as many foreign investors, have played a role with this nexus to develop either agri-business growth and exportation of legal cash crops such as sugarcane, coffee, plantains, and palm oil [150] or the illegal trafficking of drugs [151,152]. From the 1980s onwards, the low-tax land-cattle nexus, which has benefited from the ease of legalizing new properties, became a way for coca-drug traffickers to launder their quick profits. From 1985 and 1999, this new landed class aggressively acquired between 4.4 and 6 Mha of land, according to different estimates. Most of it is dedicated to cattle-ranching. At the same time, it has been estimated that, in 1998, narco-traffickers between them possessed 6 Mha or $11 \%$ of all Colombian farmland [141] (pp. 60-61).

From the 1990s, these harsh events, which have been suffered by many rural dwellers in Colombia, sometimes in very remote areas, have been closely linked with the markets of an increasingly globalized economy driven by neoliberal economic policies fostering trade openness. As a result, Colombia's production of staple foodstuffs has fallen, which makes the country increasingly dependent on imports and endangers its food security $[141,153]$. This already happened at the end of the First Globalization period (1860s-1930s), when the rapid growth of cattle-ranching and cash crops in the 1920s led to worrying food shortages in the 1930s that required a $73.5 \%$ increase in agricultural food imports between 1938 and 1939 [135]—an episode clearly represented in our series (Figures 2 and 4).

\subsubsection{Agrarian Modernization toward Industrial Farming}

The process of frontier expansion and colonization and the increase in agricultural production were the main driving forces of agrarian change in the country. Many authors have emphasized the importance of coffee in this modernization process in Colombia by changing labor relations $[73,112,130]$. Despite the state promotion of experimental stations and schools of agriculture and agronomy, the technical developments actively promoted during the first half of the twentieth century were, at first, only adopted in some regions and for some cash crops, like banana plantations in Magdalena [154-156], sugarcane in the Cauca Valley [157], and cotton in Tolima [130].

Widespread adoption of this modernization package only took place in the period from 1950 to 1970 because of a favorable combination of the availability of labor, under-used arable land, the availability of the new technologies of the Green Revolution, the interests of the agribusiness class, the growth and integration of the domestic market, and the protectionist policies [130]. However, there was a clear difference between the adoption of this Green Revolution by commercial agriculture or cash crops mainly being exported and the subsistence-oriented cultivation of staple crops by peasant smallholders. The first grabbed most of the flatlands and placed them in the hands of medium and large specialized production units to produce biomass flows marketed to processing industries and exports. Conversely, the peasant sector used hill land in small units devoted to mixed farming, which remained crucial for the domestic food supply and family survival. This "traditional" sector was affected by a shortage of suitable land as well as a lack of the business capacities and capital to "modernize" their crop production [130] (p. 269). Despite these differences, research and technological advice also helped increase yields in primary crops like cereals and potatoes. Even cattle-raising improved its yields and responded to external demand. New African grasses were introduced in lowland areas after 1970, and, in the 1980s, new breeds of cattle were adopted with the aim of producing milk and meat. There were also some improvements in infrastructure [112]. However, the most substantial changes came from poultry and pig-breeding in feed-lots.

\subsubsection{Economic Growth and Structural Changes}

The annual rate of per capita growth of the economy was 2.2\% between 1929 and 1974 . This led to structural changes in both the economy and the population as well as in urbanization and labor markets [130]. The economic value-added of agriculture decreased as a share of GDP compared to the industrial and service sectors [130]. However, after 1974, the "golden age" of economic growth ended, 
and Colombian per capita GDP growth fell to 1.8\% between 1974 and 1996 [158]. This behavior led some changes in production and extraction of the biomass.

The boom in coffee production after the 1920s boosted new activities related to processing and trading coffee in urban areas [159], but the rest of the economy also took advantage of this favorable situation. After 1930, the positive trend in international prices for coffee was reversed (see Supplementary Materials Figure S3b). Although the "coffee war" did not affect Colombia substantially [129], the fall in the terms of trade generated perverse incentives to increase the coffee-growing area and coffee production in physical terms. In a context of protectionist trade policies and the state promotion of coffee exports, as well as incipient structural change through industrial import substitution, agricultural production had to be increased to earn foreign exchange, provide inputs to food industries, raw materials to textile industries, and primary staple food to the growing population in the cities. The increment of production was possible because of some increases in yields as well as the six-fold increase in the road network and market integration during the first half of the century.

In the long run, the living standards of the population improved. Infant mortality was reduced and life expectancy increased. Biological indicators such as the average height of the population by year of birth also confirm these trends throughout the twentieth century [160]. However, this improvement has not been linear, and biological indicators vary in parallel to food availability. The average height of the population suffered a period of stagnation (1921-1935) during the food crisis that followed the rise of coffee growing at the end of the First Globalization period. It increased vigorously again after the 1960s, when cereal yields experienced a significant increase, but experienced slowing growth after the 1980s, when the agrarian system externalized the food supply and began specializing in cash crop production during the Second Globalization period.

The increases in living standards can also be related to the change in diet, especially the increased intake of animal protein [112]. However, these gains are not due to a greater supply of bovine meat, which would be expected in a country with plentiful pastures and meadows. The bovine meat supply in grams per capita fell from 1961 to 2013. The actual growth in the animal protein intake came from the increasing supply of poultry, eggs, milk, and, lastly, pigs [7]. Colombia's current consumption of animal protein is below the average for the Latin America and Caribbean region, which is very far from that in developed countries, and close to the world mean [7].

\subsection{Socioecological Impacts: Deforestation and Industrial Agribusiness}

The different socio-ecological impacts of the fund-flow metabolic changes generated through biomass extraction by Colombian agriculture can be summarized in two main groups.

1. The impact of monocultures of industrial cash crops (i.e., the degradation of soils, water bodies and landscapes, with the consequent loss of farm-associated biodiversity and ecosystem services).

2. The impact of deforestation and the resulting biodiversity loss [161].

The export-led growth of industrial crops through monocultures such as sugarcane or palm oil has been spread increasingly in Colombia by large-scale agribusinesses in the absence of either environmental regulations or their actual enforcement. It has caused substantial degradation of natural resources and agricultural landscapes. The impact on bodies of water has been forceful in some regions, such as the Cauca Valley, where actual "water grabbing" activities have deprived many communities of this vital resource [162]. The landscape degradation caused by the spread of the industrial cropping of sugarcane in the flatlands of the Cauca Valley has also undermined the ecosystem protection formerly provided by the traditional organic mixed farming carried out by small peasants from indigenous and African-descended communities, which are endowed with a bio-cultural heritage in danger of extinction, who are trying to resist these developments in the piedmont areas beyond the cash-crop frontier [163]. 
Although oil-palm expansion and projections supported by government policies are concentrated in pastureland, the oil-palm expansion threatens local food prices and food security and indirectly contributes to changes to land cover in natural areas by adding to the pressure on the land from farmers and ranchers [164]. Biofuels made with oil palm have created even more competition for water and land [165], with negative effects in species diversity, especially communities of mammalians [166]. The oil-palm expansion is also associated with violence as well as the concentration of land and wealth [167-169].

Colombian deforestation has followed different paths and drivers through time and space, which start with Andean settlement patterns, where population and economic growth have been concentrated since colonial times. From a long-term perspective country-wide, dry tropical forests and Andean forests were the first to experience a steady trend toward fragmentation and decline, while sub-humid tropical forests have only suffered a sharp decline since the second half of the twentieth century. Conversely, the humid lowland tropical forests have remained relatively well preserved until recently $[76,120]$.

Under this general picture, regional and local trends have differed spatially, and their main driving forces have also changed over time. In the highlands, deforestation has been linked to later phases in extending the agricultural frontier and higher levels of economic development. In the lowlands, conversely, it has been linked to the drivers that continue to extend the colonization frontier today. In the older highland areas, the presence of small farmers is negatively correlated with the increase in deforestation from 1985 to 2005 [170]. Other studies indicate that, in these areas, the capacity for ecological restoration through successional trajectories of the remaining dry-forest fragments is currently linked to the heterogeneity of the landscapes, which, in turn, is strongly influenced by a disturbance from farming $[163,171]$. In contrast, the advance of colonization in sub-humid and humid tropical lowland forests is correlated positively with forced migration, unsatisfied basic needs, cash crops, pastures, and illicit crops despite the greater number of protected natural areas in them. The presence of guerrillas and paramilitaries is also a key driver of these land-use changes [170,171].

In recent times (1990-2005) and at the national level, deforestation has shifted to lowland municipalities with lower populations and gentler slopes in remote areas where the presence of protected areas is greater. The growth in illegal coca cultivation in these areas, together with the expansion of pastures and oil palm in others, have become the main drivers of the deforestation of Colombia's tropical forests at present day [151,152,172,173]. These changes in land cover are causing increases in shrub land and other successional types of land cover, which are captured as a residue in our series. A recent clearing includes the Colombian Amazon where deforestation rates are even worse than in other Amazonian countries [120,174], with significant consequences in respect to the biotic homogenization of bacterial communities in the soil [10] and the carbon cycle [175]. The dry-shrub vegetation in the Llanos may also be in danger if this area becomes a new open agricultural frontier [171]. The fate of nature conservation and human development in rural Colombia depends on the peace agreement being implemented, as well as on an agrarian reform that gives peasant, indigenous, and African-descended communities greater access to the land and more secure land titles to reduce inequalities that gave rise to the armed conflict and that have been strongly reinforced by it $[152,176,177]$. Regrettably, the prospects for the peace agreement and even more for the agrarian reform are not very encouraging presently.

\section{Conclusions}

The article presents new data on NPP, extraction, and use of biomass from crops, pastures, and forest between 1915 and 2015 in Colombia. It provides a bio-physical reading of agrarian change as well as identifies the timing and features of the unsustainability of farming carried out in Colombia during the period. From a centennial perspective, the results reveal salient structural continuities, as well as significant changes over time. 
The main continuity is the enormous proportion of land and biomass flows taken up by cattle-ranching on pastureland. The grassland production and the pasture as an animal feeding were the main pieces of the biomass extracted and used in Colombia during the twentieth century. Pasture and shrub land are $40 \%$ of the land area of the country, but its increase took place after 1970, which affected the forest land especially the Andean forest, and the total NPP. The change in the land cover composition entailed a reduction of $10 \%$ of the total NPP during the twentieth century. After 1990, the NPP reduced its rate of change, but its volatility increased. The gains in yields from crops and pastures, and perhaps in the seeded forest management or the rise of coca crops, which are behind the reduction of the NPP fall, are also behind the increase of this volatility.

The land-cattle nexus as a form of land-grabbing affecting land cover and biomass extraction composition, and the behavior of the volatility in the NPP, deserves more research. This quite unusual socio-metabolic feature has nothing to do with the prevailing dietary patterns of the Colombian population. Instead, it comes from a durable mechanism of land reclamation and appropriation used by Colombian elites to prevent the poor rural population of the country having access to the open colonization frontier. The land cover changes to pasture and shrub land and the amount of biomass extracted to feed cattle reflects this capacity of the elites to grab the land of the agrarian frontier colonization and the impact of its strategy on deforestation and NPP over the whole century.

Regarding the historical changes, the dynamics of crop production and the increasing relevance of cash crops are the most relevant issues. The process of intensification and commercial specialization shifted the dominant land use patterns of Colombian cash crops from tobacco and coffee to bananas, sugarcane, palm oil, biofuels, and illegal coca, and contributed to reducing the area under staple crops. This trade-off between staple and cash crops was also affected by the economic policy of each moment. The frontier expansion in Colombia began with the coffee expansion and the insertion of Colombia into the last weave of the First Globalization, but the organic profile of the agrarian system led the country to face a tension between the allocation of resources (land and labor) to staple food and cash crop production. The state intervention during the export-led growth and especially during the stated led growth, help handle the challenge of producing biomass for the international markets and the domestic economy in expansion during the "golden age" (1967-1974).

At the middle of the century, the Green Revolution innovations were actively encouraged by the state. The support to the agrarian frontier expansion first, and the agrarian "modernization" later, are reflected in the expansion of the area harvested during the first half of the century and the increases in the yields from 1955 to 1975 . The main gains in decoupling production from land were achieved during this period, but it was a different process for staple and cash crops. Meanwhile, the area under staple crops stagnated, and its yield increases were less intensive and continuous. The cash crops achieved earlier, and higher yields and its harvested area continued to grow. Lastly, after the 1980s, new cash crops to be allocated in the international markets like palm oil or tropical fruits expanded. The area under staple and even the per capita production of grain fell, which threatened the food sovereignty of the country. The economic openness brought the chance to import food and went deeper into cash crop specialization, together with socio-ecological impacts like water grabbing and pollution, soil erosion, and biodiversity losses.

In the case of the changes in crop production and the area harvested, the role of the elites deserves more attention. Medium-sized and small-sized farmers started the frontier expansion that took place during the higher growth rate of coffee and it was supported by the economic policy of the state. The state intervention stabilized and, during the inward economic growth period the agrarian sector was modernized. However, during this period (1950-1975), interest in the cash crops advanced and, at the beginning of the 1970s, the elite slowed the hopes of land access to the small farmers and took the credit to boost their agri-business. This specialization went deeper after 1990, when the economic openness was embraced formally, at the expense of food sovereignty. The rise in cash crops relevance might also mean the start of a new trend of turning the land grabbed through pastures into more profitable export crops, which put in motion a new inner frontier of land-use intensification. 
The almost continuous support of the rural elites by the Colombia state and the persistence of the land-cattle nexus as a form of land-grabbing on the open frontiers has reinforced an unequal agrarian class structure. In this context, the socio-ecological impacts of deforestation in Colombia have been the flip side of this coin. They are currently spreading towards the lowland rainforests and the Amazon. The fate of nature conservation and fair human development is, therefore, closely linked with achieving peace and land reform.

Supplementary Materials: The following are available online at http:/ / www.mdpi.com/2071-1050/11/1/117/s1, Figure S1. (a) Maize production in thousands of tonnes $(\mathrm{Kt})$ of fresh matter from our estimation, and other sources. (b) The area under maize in thousands of hectares (Khas) from several sources and our estimation for 1915, 1925-1928, and 1932; Figure S2. (a) Yields of maize in tonnes per hectare in fresh matter from Kalmanovitz et al. and several sources in 1915, 1925-1927, and 1932. (b) Centrifuged, non-centrifuged, and total sugarcane in millions of tonnes of fresh matter (left axis) and the area under sugarcane (right axis) in thousands of hectares (Khas) during 1915-1960; Figure S3. (a) Coffee production in millions of tonnes and its area in millions of hectares (left axis). Coffee yields in tonnes per hectare (right axis). (b) Colombian coffee prices in US\$ cents per pound of Excelso coffee ( 453.6 gr.). Sources: for the coffee area and production see the text. Excelso coffee prices are from the Federación de Cafeteros de Colombia; Figure S4. (a) Data for pasture and permanent meadows from FAOSTAT and our series of pasture and shrubland \& others in millions of hectares and (b) The difference between the FAOSTAT series and our series in millions of hectares between 1961-2015; Figure S5. (a) Nutritional requirements (NR) for pigs. Our estimation and the series with the values from Krausmann et al. (b) Total nutritional requirements (TNR) for livestock. Our series (at different percentages of the body weight of cattle and adjusted by age), and the series with the values from Krausmann et al.; Figure S6. (a) Biomass extraction series in Colombia in millions of tonnes. Our series in dry matter and the others in a mix of dry and fresh matter. (b) Index numbers of the biomass extraction series 1970=1; Table S1. Coffee area and production in Colombia by departments 1915; Table S2. Literature review for factors of harvest index, root-shoot ratio, weeds in traditional, low-input and conventional agricultural systems, and NPP for pastures and tropical forest; Table S3. Crop categories and aggregations; Table S4. Annual rates of change of the forest clearing by types of forest; Table S5. Pasture, cattle and cattle density; Table S6. The evolution of the average weight by species in selected years in $\mathrm{kg}$; Table S7. Livestock feed intake for Colombia in selected years (kg dm per head/day); Table S8. NPP series in millions of tonnes of dry matter (1915-2015); Table S9. Biomass extraction and biomass use in millions of tonnes of dry matter.

Author Contributions: In writing the article A.U.-M. assembled the dataset, used the MEFA methodology to obtain the historical series, and participated in interpreting the results in light of the Colombian historiography and the scientific literature. J.I.-A. and E.T. participated in supervising the conceptualization and methodology used in the research, and in writing and revising the text. E.T. administered the research project and funding.

Funding: This research has been funded by the projects "Sustainable Farm Systems: Long-Term Socio-Ecological Metabolism in Western Agriculture" (Canadian Social Sciences and Humanities Research Council Partnership Grant 895-2011-1020), and "Sustainable Farm Systems and Transitions in Agricultural Metabolism" (Spanish Ministry of Science grant HAR2012-38920-C02-02), which has also funded the cost of this publication in Open Access.

Conflicts of Interest: The authors declare no conflict of interest.

\section{References and Notes}

1. Smil, V. Harvesting the Biosphere: How Much We Have Taken from Nature; The MIT Press: Cambridge, MA, USA, 2013; ISBN 978-0-262-01856-2.

2. Smil, V. Worldwide transformation of diets, burdens of meat production and opportunities for novel food proteins. Enzym. Microb. Technol. 2002, 30, 305-311. [CrossRef]

3. Tilman, D.; Clark, M. Global diets link environmental sustainability and human health. Nature 2014, 515, 518-522. [CrossRef] [PubMed]

4. Arizpe, N.; Giampietro, M.; Ramos-Martin, J. Food Security and Fossil Energy Dependence: An International Comparison of the Use of Fossil Energy in Agriculture (1991-2003). Crit. Rev. Plant Sci. 2011, 30, 45-63. [CrossRef]

5. Conforti, P.; Giampietro, M. Fossil energy use in agriculture: An international comparison. Agric. Ecosyst. Environ. 1997, 65, 231-243. [CrossRef]

6. Giampietro, M.; Cerretelli, G.; Pimentel, D. Energy analysis of agricultural ecosystem management: Human return and sustainability. Agric. Ecosyst. Environ. 1992, 38, 219-244. [CrossRef]

7. FAOSTAT Food and Agriculture Data. Available online: http://www.fao.org/faostat/en/ (accessed on 7 November 2018). 
8. WU Global Material Flow Data Base. Available online: http://www.materialflows.net/ (accessed on 7 November 2018).

9. Gibbs, H.K.; Ruesch, A.S.; Achard, F.; Clayton, M.K.; Holmgren, P.; Ramankutty, N.; Foley, J.A. Tropical forests were the primary sources of new agricultural land in the 1980s and 1990s. Proc. Natl. Acad. Sci. USA 2010, 107, 16732-16737. [CrossRef]

10. Rodrigues, J.L.M.; Pellizari, V.H.; Mueller, R.; Baek, K.; da C. Jesus, E.; Paula, F.S.; Mirza, B.; Hamaoui, G.S.; Tsai, S.M.; Feigl, B.; et al. Conversion of the Amazon rainforest to agriculture results in biotic homogenization of soil bacterial communities. Proc. Natl. Acad. Sci. USA 2013, 110, 988-993. [CrossRef]

11. Foley, J.A.; DeFries, R.; Asner, G.P.; Barford, C.; Bonan, G.; Carpenter, S.R.; Chapin, F.S.; Coe, M.T.; Daily, G.C.; Gibbs, H.K.; et al. Global consequences of land use. Science 2005, 309, 570-574. [CrossRef]

12. Tilman, D.; Socolow, R.; Foley, J.A.; Hill, J.; Larson, E.; Lynd, L.; Pacala, S.; Reilly, J.; Searchinger, T.; Somerville, C.; et al. Beneficial biofuels-The food, energy, and environment trilemma. Science 2009, 325, 270-271. [CrossRef]

13. Smil, V. Feeding the World: A Challenge for the Twenty-First Century; MIT Press: Cambridge, MA, USA, 2001.

14. Foley, J.A.; Ramankutty, N.; Brauman, K.A.; Cassidy, E.S.; Gerber, J.S.; Johnston, M.; Mueller, N.D.; O'Connell, C.; Ray, D.K.; West, P.C.; et al. Solutions for a cultivated planet. Nature 2011, 478, 337-342. [CrossRef]

15. Tilman, D.; Cassman, K.G.; Matson, P.A.; Naylor, R.; Polasky, S. Agricultural sustainability and intensive production practices. Nature 2002, 418, 671. [CrossRef] [PubMed]

16. Ayres, R.U. On the practical limits to substitution. Ecol. Econ. 2007, 61, 115-128. [CrossRef]

17. Bardgett, R. The Biology of Soil: A Community and Ecosystem Approach; Oxford University Press: Oxford, UK, 2005.

18. Smil, V. Crop Residues: Agriculture's Largest Harvest: Crop residues incorporate more than half of the world's agricultural phytomass. Bioscience 1999, 49, 299-308. [CrossRef]

19. Haberl, H.; Erb, K.H.; Krausmann, F.; Gaube, V.; Bondeau, A.; Plutzar, C.; Gingrich, S.; Lucht, W.; Fischer-Kowalski, M. Quantifying and mapping the human appropriation of net primary production in earth's terrestrial ecosystems. Proc. Natl. Acad. Sci. USA 2007, 104, 12942-12947. [CrossRef] [PubMed]

20. Vitousek, P.M.; Ehrlich, P.R.; Ehrlich, A.H.; Matson, P.A. Human appropriation of the products of photosynthesis. BioScience 1986, 36, 368-373. [CrossRef]

21. Haberl, H. Human appropriation of net primary production as an environmental indicator: Implications for sustainable development. Ambio 1997, 26, 143-146.

22. Schandl, H.; Grünbühel, C.; Weisz, H. Handbook of Physical Accounting: Measuring Bio-Physical Dimensions of Socio-Economic Activities; MFA-EFA-HANPP; Federal Ministry of Agriculture and Forestry, Environment and Water Management: Vienna, Austria, 2002; Division V/10.

23. Krausmann, F.; Erb, K.-H.; Gingrich, S.; Haberl, H.; Bondeau, A.; Gaube, V.; Lauk, C.; Plutzar, C.; Searchinger, T.D. Global human appropriation of net primary production doubled in the 20th century. Proc. Natl. Acad. Sci. USA 2013, 110, 10324-10329. [CrossRef] [PubMed]

24. Gingrich, S.; Niedertscheider, M.; Kastner, T.; Haberl, H.; Cosor, G.; Krausmann, F.; Kuemmerle, T.; Müller, D.; Reith-Musel, A.; Jepsen, M.R.; et al. Exploring long-term trends in land use change and aboveground human appropriation of net primary production in nine European countries. Land Use Policy 2015, 47, 426-438. [CrossRef]

25. Bringezu, S.; Schütz, H. Material Use Indicators for the European Union, 1980-1997; Eurostat: Luxembourg, 2001.

26. Eurostat. Economy Wide Material Flow Accounts: Compilation Guidelines for Reporting to the 2009 Eurostat Questionnaire. Available online: https:/ / unstats.un.org/unsd/envaccounting/ceea/archive/Framework/ Eurostat\%20MFA\%20compilation\%20guide_2009.pdf (accessed on 7 November 2018).

27. Fischer-Kowalski, M.; Krausmann, F.; Giljum, S.; Lutter, S.; Mayer, A.; Bringezu, S.; Moriguchi, Y.; Schütz, H.; Schandl, H.; Weisz, H. Methodology and indicators of economy-wide material flow accounting: State of the art and reliability across sources. J. Ind. Ecol. 2011, 15, 855-876. [CrossRef]

28. Soto, D.; Infante-Amate, J.; Guzmán, G.I.; Cid, A.; Aguilera, E.; García, R.; González de Molina, M. The social metabolism of biomass in Spain, 1900-2008: From food to feed-oriented changes in the agro-ecosystems. Ecol. Econ. 2016, 128, 130-138. [CrossRef] 
29. Risku-Norja, H.; Mäenpää, I. MFA model to assess economic and environmental consequences of food production and consumption. Ecol. Econ. 2007, 60, 700-711. [CrossRef]

30. Risku-Norja, H. The Total Material Requirement-Concept Applied to Agriculture: A Case Study from Finland. Agric. Food Sci. 1999, 8, 393-410. [CrossRef]

31. Kovanda, J.; Hak, T. Historical perspectives of material use in Czechoslovakia in 1855-2007. Ecol. Indic. 2011, 11, 1375-1384. [CrossRef]

32. Kuskova, P.; Gingrich, S.; Krausmann, F. Long term changes in social metabolism and land use in Czechoslovakia, 1830-2000: An energy transition under changing political regimes. Ecol. Econ. 2008, 68, 394-407. [CrossRef]

33. Krausmann, F.; Erb, K.-H.; Gingrich, S.; Lauk, C.; Haberl, H. Global patterns of socioeconomic biomass flows in the year 2000: A comprehensive assessment of supply, consumption and constraints. Ecol. Econ. 2008, 65, 471-487. [CrossRef]

34. Wirsenius, S. The Biomass Metabolism of the Food System: A Model-Based Survey of the Global and Regional Turnover of Food Biomass. J. Ind. Ecol. 2003, 7, 47-80. [CrossRef]

35. The World Bank Data. Available online: https://data.worldbank.org/indicator/NY.GDP.PCAP.CD? locations=CO-CL-BR-AR-EC-PE-BO-PY-UY-VE (accessed on 7 November 2018).

36. Sistema Nacional Ambiental Sistema de Información Sobre la Biodiversidad de Colombia. Available online: https:/ / sibcolombia.net/actualidad/biodiversidad-en-cifras/ (accessed on 7 November 2018).

37. Steinmann, Z.J.N.; Schipper, A.M.; Hauck, M.; Giljum, S.; Wernet, G.; Huijbregts, M.A.J. Resource footprints are good proxies of environmental damage. Environ. Sci. Technol. 2017, 51, 6360-6366. [CrossRef]

38. Heijungs, R. Comment on "Resource Footprints are Good Proxies of Environmental Damage". Environ. Sci. Technol. 2017, 51, 13054-13055. [CrossRef]

39. Steinmann, Z.J.N.; Schipper, A.M.; Hauck, M.; Giljum, S.; Wernet, G.; Huijbregts, M.A.J. Response to Comment on "Resource Footprints are Good Proxies of Environmental Damage". Environ. Sci. Technol. 2017, 51, 13056-13057. [CrossRef]

40. Giljum, S.; Eisenmenger, N. North-South trade and the distribution of environmental goods and burdens: A biophysical perspective. J. Environ. Dev. 2004, 13, 73-100. [CrossRef]

41. Muradian, R.; Martinez-Alier, J. Trade and the environment: From a 'Southern' perspective. Ecol. Econ. 2001, 36, 281-297. [CrossRef]

42. Muradian, R.; Martinez-Alier, J. South-North materials flow: History and environmental repercussions. Innovation 2001, 14, 171-187. [CrossRef]

43. Muradian, R.; Martinez-Alier, J. Globalization and Poverty: An Ecological Perspective; Heinrich Böll Foundation: Cologne, Germany, 2001.

44. Schandl, H.; Schulz, N. Changes in the United Kingdom's natural relations in terms of society's metabolism and land-use from 1850 to the present day. Ecol. Econ. 2002, 41, 203-221. [CrossRef]

45. Krausmann, F.; Schandl, H.; Sieferle, R.P. Socio-ecological regime transitions in Austria and the United Kingdom. Ecol. Econ. 2008, 65, 187-201. [CrossRef]

46. Infante-Amate, J.; Soto, D.; Aguilera, E.; García-Ruiz, R.; Guzmán, G.; Cid, A.; González de Molina, M. The Spanish Transition to Industrial Metabolism: Long-Term Material Flow Analysis (1860-2010). J. Ind. Ecol. 2015, 19, 866-876. [CrossRef]

47. Singh, S.J.; Krausmann, F.; Gingrich, S.; Haberl, H.; Erb, K.-H.; Lanz, P.; Martinez-Alier, J.; Temper, L. India's biophysical economy, 1961-2008. Sustainability in a national and global context. Ecol. Econ. 2012, 76, 60-69. [CrossRef] [PubMed]

48. Vilaysouk, X.; Schandl, H.; Murakami, S. Improving the knowledge base on material flow analysis for Asian developing countries: A case study of Lao PDR. Resour. Conserv. Recycl. 2017, 127, 179-189. [CrossRef]

49. Russi, D.; González Martínez, A.C.; Silva-Macher, J.C.; Giljum, S.; Martínez Alier, J.; Vallejo, M.C. Material Flow Accounting in Chile, Ecuador, Mexico and Peru (1980-2000). J. Ind. Ecol. 2008, 12, 704-720. [CrossRef]

50. Amann, C.; Bruckner, W.; Fischer-Kowalski, M.; Grünbühel, C. Material Flow Accounting in Amazonia: A Tool for Sustainable Development; Inst. for Interdisciplinary Studies at Austrian Universities, Department of Social Ecology: Viena, Austria, 2002.

51. Vallejo, M.C.; Pérez Rincón, M.A.; Martinez-Alier, J. Metabolic profile of the Colombian Economy from 1970 to 2007. J. Ind. Ecol. 2011, 15, 245-267. [CrossRef] 
52. Pérez-Rincón, M.; Vargas-Morales, J.; Crespo-Marín, Z. Trends in social metabolism and environmental conflicts in four Andean countries from 1970 to 2013. Sustain. Sci. 2018, 13, 635-648. [CrossRef]

53. Behrens, A.; Giljum, S.; Kovanda, J.; Niza, S. The material basis of the global economy: Worldwide patterns of natural resource extraction and their implications for sustainable resource use policies. Ecol. Econ. 2007, 64, 444-453. [CrossRef]

54. Schandl, H.; Fischer-Kowalski, M.; West, J.; Giljum, S.; Dittrich, M.; Eisenmenger, N.; Geschke, A.; Lieber, M.; Wieland, H.P.; Schaffartzik, A.; et al. Global Material Flows and Resource Productivity. Assessment Report for the UNEP International Resource Panel. Pre-Publication Final Draft; United Nations Environment Programme: Paris, France, 2017.

55. Schandl, H.; Fischer-Kowalski, M.; West, J.; Giljum, S.; Dittrich, M.; Eisenmenger, N.; Geschke, A.; Lieber, M.; Wieland, H.P.; Schaffartzik, A.; et al. Global Material Flows and Resource Productivity; United Nations Environment Programme: Nairobi, Kenya, 2016.

56. Steinberger, J.K.; Krausmann, F.; Eisenmenger, N. Global patterns of materials use: A socioeconomic and geophysical analysis. Ecol. Econ. 2010, 69, 1148-1158. [CrossRef]

57. Giljum, S. Trade, materials flows, and economic development in the South: The example of Chile. J. Ind. Ecol. 2004, 8, 241-261. [CrossRef]

58. Guzmán Casado, G.; Aguilera, E.; Soto Fernández, D.; Cid, A.; Infante Amate, J.; García Ruiz, R.; Herrera, A.; Villa, I.; González de Molina, M. Methodology and Conversion Factors to Estimate the Net Primary Productivity of Historical and Contemporary Agroecosystems. Available online: https: / /ideas.repec.org/p/seh/wpaper/1407.html (accessed on 7 November 2018).

59. Eurostat. Economic-wide Material Flow Accounts (EW-MFA). 2013. Available online: https: / / ec.europa.eu/eurostat/documents /1798247/6191533/2013-EW-MFA-Guide-10Sep2013.pdf/ 54087dfb-1fb0-40f2-b1e4-64ed22ae3f4c (accessed on 7 November 2018).

60. Galán, E.; Padró, R.; Marco, I.; Tello, E.; Cunfer, G.; Guzmán, G.I.; Golzález de Molina, M.; Krausmann, F.; Gingrich, S.; Sacristán, V.; et al. Widening the analysis of Energy Return on Investment (EROI) in agro-ecosystems: Socio-ecological transitions to industrialized farm systems (the Vallès County, Catalonia, c. 1860 and 1999). Ecol. Model. 2016, 336, 13-25. [CrossRef]

61. Guzmán, G.I.; González de Molina, M. Energy in Agroecosystems. A Tool for Assessing Sustainability; CRC Press: Boca Raton, FL, USA, 2017.

62. Tello, E.; Galán, E.; Sacristán, V.; Cunfer, G.; Guzmán, G.I.; de Molina, M.G.; Krausmann, F.; Gingrich, S.; Padró, R.; Marco, I.; et al. Opening the black box of energy throughputs in farm systems: A decomposition analysis between the energy returns to external inputs, internal biomass reuses and total inputs consumed (the Vallès County, Catalonia, c. 1860 and 1999). Ecol. Econ. 2016, 121, 160-174. [CrossRef]

63. Flórez Nieto, C.E.; Méndez, R. Las Trasformaciones Socio Demográficas en Colombia Durante el Siglo XX; Mundo, T., Ed.; Banco de la República: Bogotá, Colombia, 2000.

64. Anuario estadístico. Colombia, D. G. de estadística, Ed.; Bogotá, Colombia, 1915.

65. Anuario estadístico. Colombia, D. G. de estadística, Ed.; Bogotá, Colombia, 1933.

66. Anuario estadístico. Colombia, D. G. de estadística, Ed.; Bogotá, Colombia, 1934.

67. Anuario estadístico. Colombia, D. G. de estadística, Ed.; Bogotá, Colombia, 1937.

68. Wylie, K.H. The Agriculture of Colombia; U. S. Department of Agriculture: Washington, DC, USA, 1942.

69. Atkinson, L.J. Changes in Agricultural Production and Technology in Colombia; Dept. of Agriculture, Economic Research Service in cooperation with the Ministry of Agriculture and the Central Planning Agency of Colombia: Washington, DC, USA, 1969.

70. Sanchez Santamaria, I. Geografía Comercial y Económica de Colombia y de los Países con los Cuales Negocia; Edit. Specta: Bogotá, Colombia, 1928.

71. Diot, J. Colombia económica 1923-1929. Bol. Mens. Estad. 1976, 300, 120-245.

72. SAC. Revista Nacional de Agricultura; SAC: Bogotá, Colombia, 1925.

73. Bejarano, J.A. Antología Jesús Antonio Bejarano; Universidad Nacional de Colombia, Vicerrectoría Académica: Bogotá, Colombia, 2011.

74. Varela Martínez, R. Boletín de la Economía Agrícola de Colombia; Ministerio de Agricultura y Ganadería, Division de Economía Rural: Bogotá, Colombia, 1949.

75. Kalmanovitz, S.; López, E.; Romero, C.A. La Producción Agropecuaria Colombiana 1915-1950; Banco de la República: Bogotá, Colombia, 1999. 
76. Etter, A.; McAlpine, C.; Possingham, H. Historical Patterns and Drivers of Landscape Change in Colombia Since 1500: A Regionalized Spatial Approach. Ann. Assoc. Am. Geogr. 2008, 98, 2-23. [CrossRef]

77. Sistema de Monitoreo de Bosques y Carbono. Available online: http://smbyc.ideam.gov.co/MonitoreoBCWEB/reg/indexLogOn.jsp (accessed on 7 November 2018).

78. Pizano, C.; García, H. El Bosque Seco Tropical en Colombia; Instituto de Investigación de Recursos Biológicos: Bogotá, Colombia, 2014.

79. Leyva, P. El Medio Ambiente en Colombia; IDEAM: Bogotá, Colombia, 2001.

80. DANE. Censo Agropecuario 1960; DANE: Bogotá, Colombia, 1964.

81. DANE. Censo Nacional Agropecuario 1970-71; DANE: Bogotá, Colombia, 1974.

82. Unidad de Planeación Minero Energética, Balance energético Colombiano (BECO) 1975-2016. Available online: http://www1.upme.gov.co/InformacionCifras/Paginas/BalanceEnergetico.aspx (accessed on 7 November 2018).

83. Anuario estadístico: Comercio exterior. Colombia, D. G. de E., Ed.; Bogotá, Colombia, 1923.

84. Anuario estadístico: Comercio exterior. Colombia, D. G. de E., Ed.; Bogotá, Colombia, 1938.

85. Anuario estadístico: Comercio exterior. Colombia, D. G. de E., Ed.; Bogotá, Colombia, 1945.

86. Anuario estadístico: Comercio exterior. Colombia, D. A. N. de E., Ed.; Bogotá, Colombia, 1955.

87. Anuario estadístico: Comercio exterior. Colombia, D. G. de E., Ed.; Bogotá, Colombia, 1916.

88. Argentina., M. De Agricultura; Estadística Agrícola; [s.n.], 1910.

89. Argentina., M. De Agricultura; Estadística Agrícola; [s.n.], 1926.

90. Anuario Estadístico 1925. 1926.

91. Memoria del Censo Agrícola Nacional 1946, Ministerio de Agricultura de Cuba; P. Fernández: Habana, 195.

92. de E Ecuador, D.N. Ecuador en Cifras: 1938-1942; Dirección Nacional de Estadística: Quito, Ecuador, 1944.

93. United Nations. El Desarrollo Económico del Ecuador; Banco Central del Ecuador: Quito, Ecuador, 1953.

94. Montero, A. Café, Revolución Verde, Regulación y Liberación del Mercado: Costa Rica (1950-2017); Universitat de Barcelona: Barcelona, España, 2018.

95. Scurlock, J.M.O.; Olson, R.J. NPP Multi-Biome: Grassland, Boreal Forest, and Tropical Forest Sites, 1939-1996, R1. Available online: https:/ / daac.ornl.gov/NPP/guides/NPP_MULTIBIOME.html (accessed on 7 November 2018).

96. Cobertura de la Tierra Metodología CORINE Land Cover adaptada para Colombia durante el periodo 2010-2012. Escala 1: 100000. Available online: http://siatac.co/c/document_library/get_file?uuid= a64629ad-2dbe-4e1e-a561-fc16b8037522\&groupId=762 (accessed on 7 November 2018).

97. DANE. Tercer Censo Nacional Agropecuario-2014; DANE: Bogotá, Colombia, 2016.

98. Borda, V.H.; Ram Nader, L.M. Disponibilidad forrajera en pasturas renovadas de Kikuyo, Pennisetum clandestinum Hoechst, con un equipo renovador para tracción animal. Región alto andina de Barragán, Tuluá, Valle del Cauca, Colombia. Acta Agron. 2003, 52, 77-83.

99. Gómez, I.A.; Gallopin, G.C. Estimación de la productividad primaria neta de ecosistemas terrestres del mundo en relación a factores ambientales. Ecol. Austral 1991, 1, 24-40.

100. Raich, J.W.; Rastetter, E.B.; Melillo, J.M.; Kicklighter, D.W.; Steudler, P.A.; Peterson, B.J.; Grace, A.L.; Moore III, B.; Vorosmarty, C.J. Potential net primary productivity in South America: Application of a global model. Ecol. Appl. 1991, 1, 399-429. [CrossRef] [PubMed]

101. Moreno Durango, O.; Padilla Valle, H. Evaluación de Cuatro Gramíneas Tropicales Para la Producción de Leche. Acta Agronómica 1972, 22, 163-183.

102. Padilla Quintero, A. Estimación de la Productividad Primaria Neta Aérea (PPNA) del Forraje de Pastos para los Sistemas de Producción Ganadera Mediante Sensores Remotos; Universidad del Valle: Cali, Colombia, 2017.

103. Nutrient Requirements of Horses. Available online: https://nrc88.nas.edu/nrh/ (accessed on 7 November 2018).

104. National Research Council. Nutrient Requirements of Swine; National Academies Press: Washington, DC, USA, 1998.

105. National Research Council. Nutrient Requirements of Sheep; National Academies: Washington, DC, USA, 1985; Volume 5 .

106. Mamoon, R. Goats and Their Nutrition; Manitoba GOAT Association: MacGregor, MB, Canada, 2008.

107. Varela Martínez, R.; Palacio del Valle, G.; Cañón, J.; Ramírez, E. Economía Agropecuaria de Colombia en 1950; Ministerio de Agricultura: Bogotá, Colombia, 1952. 
108. Banrepcultural. Boletín de Estadística de Colombia. Available online: http://babel.banrepcultural.org/ cdm/ref/collection/p17054coll26/id/94 (accessed on 7 November 2018).

109. Hertford, R.; Nores, G.A.; Ardila, J.; Londoño, H.; Rivas Rios, L.; Trujillo, C. Caracterización del Sector Ganadero de Colombia 1953 a 1975; Centro Internacional de Agricultura Tropical (CIAT): Cali, Colombia, 1982.

110. Encuestas de Sacrificio de Ganado (2010-2018). Available online: https://www.dane.gov.co/index. php/estadisticas-por-tema/agropecuario/encuesta-de-sacrificio-de-ganado/encuesta-de-sacrificio-deganado-esag-historicos (accessed on 7 November 2018).

111. Etter, A.; van Wyngaarden, W. Patterns of landscape transformation in Colombia, with emphasis in the Andean region. Ambio 2000, 29, 432-439. [CrossRef]

112. Kalmanovitz, S.; López, E. La Agricultura Colombiana en el Siglo XX; Fondo de Cultura Económica: Bogotá, Colombia, 2006.

113. Centro de Memoria Histórica Base de datos ¡Basta ya!: Secuestros 1970-2010. Available online: http:/ /www. centrodememoriahistorica.gov.co/micrositios/informeGeneral/basesDatos.html (accessed on 7 November 2018).

114. Fischer-Kowalski, M.; Haberl, H. Socioecological Transitions and Global Change: Trajectories of Social Metabolism and Land Use; Edward Elgar Publishing: Cheltenham, UK, 2007.

115. Steffen, W.; Broadgate, W.; Deutsch, L.; Gaffney, O.; Ludwig, C. The trajectory of the Anthropocene: The great acceleration. Anthr. Rev. 2015, 2, 81-98. [CrossRef]

116. Kander, A.; Malanima, P.; Warde, P. Power to the People: Energy in Europe over the Last Five Centuries; Princeton University Press: Princeton, NJ, USA, 2014.

117. González de Molina, M.; Toledo, V.M. The Social Metabolism. A Socio-Ecological Theory of Historical Change; Springer International Publishing: Cham, Switzerland, 2014.

118. Sieferle, R.P. The Subterranean Forest: Energy Systems and the Industrial Revolution; White Horse Press: Winwick, UK, 2001.

119. Erb, K.-H.; Krausmann, F.; Gaube, V.; Gingrich, S.; Bondeau, A.; Fischer-Kowalski, M.; Haberl, H. Analyzing the global human appropriation of net primary production-Processes, trajectories, implications. An introduction. Ecol. Econ. 2009, 69, 250-259. [CrossRef]

120. Etter, A.; McAlpine, C.; Wilson, K.; Phinn, S.; Possingham, H. Regional patterns of agricultural land use and deforestation in Colombia. Agric. Ecosyst. Environ. 2006, 114, 369-386. [CrossRef]

121. Carbó, E.P. El Caribe Colombiano: Una Historia Regional (1870-1950); Banco de la República: Bogotá, Colombia, 1998.

122. Pellegrini, P.; Fernández, R.J. Crop intensification, land use, and on-farm energy-use efficiency during the worldwide spread of the green revolution. Proc. Natl. Acad. Sci. USA 2018, 115, 2335-2340. [CrossRef] [PubMed]

123. Rudel, T.K.; Coomes, O.T.; Moran, E.; Achard, F.; Angelsen, A.; Xu, J.; Lambin, E. Forest transitions: Towards a global understanding of land use change. Glob. Environ. Chang. 2005, 15, 23-31. [CrossRef]

124. Etter, A.; McAlpine, C.; Pullar, D.; Possingham, H. Modelling the conversion of Colombian lowland ecosystems since 1940: Drivers, patterns and rates. J. Environ. Manag. 2006, 79, 74-87. [CrossRef]

125. Cárdenas, E.; Ocampo, J.; Thorp, R. An Economic History of Twentieth-Century Latin America: Volume I: The Export Age; Springer: Berlin, Germany, 2000.

126. Ocampo, J.A. Café, Industria Y Macroeconomía: Ensayos de Historia Económica Colombia; Fondo de Cultura Económica: Bogotá, Colombia 2015.

127. Palacios, M. El Café en Colombia, 1850-1970: Una Historia Económica, Social y Política; Áncora: Bogotá, Colombia, 1983.

128. Palacio, G.; González, J.M.; Yepes, F.; Carrizosa, J.; Palacio, L.C.; Montoya, C.; Márquez, G. Naturaleza en Disputa. Ensayos de Historia Ambiental en Colombia 1850-1995; Universidad Nacional de Colombia: Bogotá, Colombia, 2001.

129. An Economic History of Twentieth-Century Latin America. Volume 2: Latin America in the 1930s. The Role of the Periphery in World Crisis; Palgrave Macmillan: Basingstoke, UK, 2000.

130. Cárdenas, E.; Ocampo, J.; Thorp, R. An Economic History of Twentieth-Century Latin America: Volume 3: Industrialization and the State in Latin America: The Postwar Years; Springer: Berlin, Germany, 2000.

131. Bértola, L.; Ocampo, J.A. The Economic Development of Latin America Since Independence; OUP: Oxford, UK, 2012. 
132. Villaveces, N.J.; Sánchez, F. Tendencias Históricas y Regionales de la Adjudicación de Baldios en Colombia 1900-2012; de los Andes, U., Ed.; Serie Documentos Cede; Universidad Del Rosario: Bogotá, Colombia, 2014.

133. LeGrand, C. Frontier Expansion and Peasant Protest in Colombia, 1850-1936; University of New Mexico Press: Albuquerque, NM, USA, 1986.

134. Ocampo, J.A. Historia Economica de Colombia; Tercer Mundo Editores: Bogotá, Colombia, 1994.

135. Arango Restrepo, M. Esquema de Políticas de Reforma Agraria en Colombia. Available online: http: / / tesis.udea.edu.co/handle/10495/4281 (accessed on 7 November 2018).

136. Callejas, A.D. Colombia: La Reforma Agraria y Sus Documentos Fundamentales; Universidad de Cartagena: Cartagena, Colombia, 2002.

137. Kalmanovitz, S. Economía y Nación: Una Breve Historia de Colombia; Editorial Norma: Bogotá, Colombia, 2003.

138. Castellanos Sierra, M. La Colonización Estatal en el Caquetá y su Incidencia en la Generación de Conflictos Socio-Ambientales; 2018.

139. Urueña, B.M.T. Colonización Campesina en Putumayo-Colombia; 2018.

140. Van Ausdal, S. Ni Calamidad ni Panacea: Una Reflexión en Torno a la Historiografía de la Ganadería Colombiana. In El poder de la carne. Historias de ganaderías en la primera mitad del siglo XX en Colombia; Universidad Javeriana-Colciencias: Bogotá, Colombia, 2008; pp. 29-46.

141. Richani, N. The agrarian rentier political economy: Land concentration and food insecurity in Colombia. Lat. Am. Res. Rev. 2012, 47, 51-78. [CrossRef]

142. Van Ausdal, S. Pasture, profit, and power: An environmental history of cattle ranching in Colombia, 1850-1950. Geoforum 2009, 40, 707-719. [CrossRef]

143. Benitez, R.M. La Problemática de la Agricultura Tradicional Campesina; Contraloría General de la República: Bogotá, Colombia, 2001.

144. Machado, A. El Mercado de Tierras en Colombia: Una Alternativa Viable? Tercer Mundo: Bogotá, Colombia, 1999.

145. Salgado, C. Propuestas Frente a las Restricciones Estructurales y Políticas Para la Reparación Efectiva de las Tierras Perdidas por la Población Desplazada; CODHES: Bogotá, Colombia, 2008.

146. Ballvé, T. Territories of life and death on a Colombian frontier. Antipode 2013, 45, 238-241. [CrossRef]

147. Borras, S.M., Jr.; Franco, J.C.; Gómez, S.; Kay, C.; Spoor, M. Land grabbing in Latin America and the Caribbean. J. Peasant Stud. 2012, 39, 845-872. [CrossRef]

148. Grajales, J. The rifle and the title: Paramilitary violence, land grab and land control in Colombia. J. Peasant Stud. 2011, 38, 771-792. [CrossRef]

149. Giugale, M.; Lafourcade, O.; Luff, C. Colombia: The Economic Foundation of Peace; World Bank Publications: Washington, DC, USA, 2003.

150. Maher, D. Rooted in violence: Civil war, international trade and the expansion of palm oil in Colombia. New Political Econ. 2015, 20, 299-330. [CrossRef]

151. Rincón-Ruiz, A.; Pascual, U.; Romero, M. An exploratory spatial analysis of illegal coca cultivation in Colombia using local indicators of spatial association and socioecological variables. Ecol. Indic. 2013, 34, 103-112. [CrossRef]

152. Borón, V.; Payán, E.; MacMillan, D.; Tzanopoulos, J. Achieving sustainable development in rural areas in Colombia: Future scenarios for biodiversity conservation under land use change. Land Use Policy 2016, 59, 27-37. [CrossRef]

153. Fajardo, D. La tierra y el poder político; la reforma agraria y la reforma rural en Colombia. Rev. Reforma Agrar. Colon. Coop. 2002, 1, 4-20.

154. Bucheli, M. Bananas and Business: The United Fruit Company in Colombia, 1899-2000; NYU Press: New York, NY, USA, 2005.

155. Bucheli, M. Enforcing Business Contracts in South America: The United Fruit Company and Colombian Banana Planters in the Twentieth Century. Bus. Hist. Rev. 2004, 78, 181-212. [CrossRef]

156. Ellis, F. Las Transnacionales del Banano en Centroamérica; Universidad de Costa Rica: San José, Costa Rica, 1983.

157. Delgadillo-Vargas, O. La Caña de Azúcar en la Historia Ambiental del valle Geográfico del río Cauca (1864-2010); Universida del Javeriana de Colombia: Cali, Colombia, 2014.

158. GRECO. El Crecimiento Económico Colombiano en el Siglo XX: Aspectos Globales; Banco de la República: Bogotá, Colombia, 1999. 
159. Ramírez Bacca, R. Clase obrera urbana en la industria del café. Escogedoras, trilladoras y régimen laboral en Antioquia, 1910-1942. Rev. Desarro. Soc. 2010, 66, 115-144.

160. Meisel-Roca, A.; Ramírez-Giraldo, M.T.; Santos-Cárdenas, D. Socioeconomic Determinants and Spatial Convergence of Biological Well-Being: The Case of Physical Stature in Colombia, 1920-1990; Banco de la República: Bogotá, Colombia, 2018.

161. Jarvis, A.; Touval, J.L.; Schmitz, M.C.; Sotomayor, L.; Hyman, G.G. Assessment of threats to ecosystems in South America. J. Nat. Conserv. 2010, 18, 180-188. [CrossRef]

162. Vélez Torres, I. Water Grabbing in the Cauca Basin: The Capitalist Exploitation of Water and Dispossession of Afro-Descendant Communities. Water Altern. 2012, 5, 431-449.

163. Marull, J.; Delgadillo, O.; Cattaneo, C.; La Rota, M.J.; Krausmann, F. Socioecological transition in the Cauca river valley, Colombia (1943-2010): Towards an energy-landscape integrated analysis. Reg. Environ. Chang. 2018, 18, 1073-1087. [CrossRef]

164. Castiblanco, C.; Etter, A.; Aide, T.M. Oil palm plantations in Colombia: A model of future expansion. Environ. Sci. Policy 2013, 27, 172-183. [CrossRef]

165. de Fraiture, C.; Giordano, M.; Liao, Y. Biofuels and implications for agricultural water use: Blue impacts of green energy. Water Policy 2008, 10, 67-81. [CrossRef]

166. Pardo, L.E.; de Oliveira Roque, F.; Campbell, M.J.; Younes, N.; Edwards, W.; Laurance, W.F. Identifying critical limits in oil palm cover for the conservation of terrestrial mammals in Colombia. Biol. Conserv. 2018, 227, 65-73. [CrossRef]

167. Castiblanco, C.; Etter, A.; Ramirez, A. Impacts of oil palm expansion in Colombia: What do socioeconomic indicators show? Land Use Policy 2015, 44, 31-43. [CrossRef]

168. Colombia Rural, Razones Para la Esperanza. Informe Nacional de Desarrollo Humano 2011. Available online: http:/ / www.undp.org/content/dam/colombia/docs/DesarrolloHumano/undp-co-ic_indh2011parte1-2011.pdf (accessed on 7 November 2018).

169. Centro Nacional de Memoria Histórica. Basta ya! Colombia: Memorias de Guerra y Dignidad; Centro Nacional de Memoria Histórica: Bogotá, Colombia, 2013.

170. Armenteras, D.; Rodríguez, N.; Retana, J.; Morales, M. Understanding deforestation in montane and lowland forests of the Colombian Andes. Reg. Environ. Chang. 2011, 11, 693-705. [CrossRef]

171. Castellanos-Castro, C.; Newton, A.C. Environmental heterogeneity influences successional trajectories in Colombian seasonally dry tropical forests. Biotropica 2015, 47, 660-671. [CrossRef]

172. Dávalos, L.M.; Bejarano, A.C.; Hall, M.A.; Correa, H.L.; Corthals, A.; Espejo, O.J. Forests and drugs: Coca-driven deforestation in tropical biodiversity hotspots. Environ. Sci. Technol. 2011, 45, 1219-1227. [CrossRef]

173. Chadid, M.A.; Dávalos, L.M.; Molina, J.; Armenteras, D. A Bayesian spatial model highlights distinct dynamics in deforestation from coca and pastures in an Andean biodiversity hotspot. Forests 2015, 6, 3828-3846. [CrossRef]

174. Armenteras, D.; Rudas, G.; Rodriguez, N.; Sua, S.; Romero, M. Patterns and causes of deforestation in the Colombian Amazon. Ecol. Indic. 2006, 6, 353-368. [CrossRef]

175. Dymond, C.C.; Spittlehouse, D.L. Forests in a Carbon-Constrained World. Available online: https://www. for.gov.bc.ca/hfd/pubs/Docs/En/En92.pdf (accessed on 7 November 2018).

176. Clerici, N.; Richardson, J.E.; Escobedo, F.J.; Posada, J.M.; Linares, M.; Sanchez, A.; Vargas, J.F. Colombia: Dealing in conservation. Science 2016, 354, 190. [CrossRef] [PubMed]

177. Baptiste, B.; Pinedo-Vasquez, M.; Gutierrez-Velez, V.H.; Andrade, G.I.; Vieira, P.; Estupiñán-Suárez, L.M.; Londoño, M.C.; Laurance, W.; Lee, T.M. Greening peace in Colombia. Nat. Ecol. Evol. 2017, 1, 102. [CrossRef] [PubMed]

(C) 2018 by the authors. Licensee MDPI, Basel, Switzerland. This article is an open access article distributed under the terms and conditions of the Creative Commons Attribution (CC BY) license (http:/ / creativecommons.org/licenses/by/4.0/). 